Review Article

\title{
A REVIEW ON ANTI-HCV AGENTS TARGETING ACTIVE SITE AND ALLOSTERIC SITES OF NON- STRUCTURAL PROTEIN 5B [NS5B]
}

\author{
PRASANTHI POLAMREDDYab*, VINITA VISHWAKARMAª, RAMBABU GUNDLA ${ }^{\text {bc }}$
}

aCentre for Nanoscience and Nanotechnology, Sathyabama University, Jeppiaar Nagar, Old Mahabalipuram Road, Chennai 600119, India, bDiscovery Research, GVK Biosciences, IDA, Mallapur, Hyderabad 500076, India, cDepartment of Chemistry, GITAM School of Technology, HTP Campus, GITAM University, Hyderabad 502329, TS, India

Email: prasu.sesri@gmail.com

Received: 08 Jul 2016 Revised and Accepted: 09 Sep 2016

\begin{abstract}
Hepatitis $\mathrm{C}$, a chronic disease affecting the global population significantly is caused majorly by Hepatitis $\mathrm{C}$ virus [HCV]. Among the several druggable targets explored for Hepatitis C, the viral protein, non-structural protein 5B [NS5B] is the target of choice for researchers as it is the key enzyme in the HCV replication and its active site is conserved among all genotypes. In the recent years the landscape of Hepatitis $\mathrm{C}$ therapies, have evolved from Peg-Interferon [PEG-INF]/Ribavirin, to directly acting anti-virus along with PEG-INF and finally, INF free regimens with greater than 90\% sustained virological response [SVR]. The launch of Sofosbuvir, a nucleotide inhibitor of NS5B marks the major paradigm in hepatitis C research. Sofosbuvir exhibits, pan-genotypic activity, low barrier to resistance, highly effective and safe. However, the high prices of these medications limit their universal access. This review will focus on progress towards the discovery and development of NS5B inhibitors targeting allosteric sites and active site, covering the chemical class and structure-activity relationships.
\end{abstract}

Keywords: Hepatitis C virus, NS5B, Inhibitors, Structure-Activity relationships, Genotypic variance, Allosteric site, Active site

(C) 2016 The Authors. Published by Innovare Academic Sciences Pvt Ltd. This is an open access article under the CC BY license (http://creativecommons. org/licenses/by/4. 0/) DOI: http://dx.doi.org/10.22159/ijpps.2016v8i11.13965

\section{INTRODUCTION}

Hepatitis means inflammation (a painful reddish swelling) of the liver and Hepatitis $\mathrm{C}$ virus (HCV) is one of the major causes. HCV can spread through many ways ranging from a blood transfusion, poorly sterilized medical equipment, from the mother (HCV carrier) to the baby, being tattooed with unsterilized tools, having unprotected sex with an infected person and sharing of personal care items [1]. About $80 \%$ of those infected with HCV develop chronic infection [2]. Patients can relapse and develop infection due to the presence of variants of the virus [quasispecies] arising from error-prone replication [3].

The World Health Organization [WHO] has estimated that almost $3.3 \%$ of world's population has been suffering from HCV infection. About 2-3 million people in the U. S. A, 4-10 million people in Europe and close to 12 million people in India suffer from $\mathrm{HCV}$ infection [4, 5]. A combination of Pegylated Interferon [weekly injections] and Ribavirin [daily oral], given for a period of 24 or $48 \mathrm{w}$, depending on the HCV genotype was the potential treatment option available till 2011 [6]. Improved outcomes are seen in 50-60\% of patients infected with genotype 1 and 4 , but were effective in 70-90\% of genotype 2 and 3 infected population. However, adverse effects like flu like symptoms are more common. Later in 2011 first generation direct acting anti-virals [DAA]-NS3/4A protease inhibitors namely Telaprevir [Incivek], Boceprevir [Victrelis] were launched, but their use is restricted to patients infected with HCV genotype $1[6,7]$. Over a decade efforts were focused towards development of specific inhibitors of the viral RNA-dependent RNA polymerase NS5B as it is the key enzyme for viral replication, conserved among the HCV genotypes 1, 2, 3, 4, 5 and 6, has an active site and many allosteric binding pockets [8]. A major breakthrough in Hepatitis C research came with the launch of Sofosbuvir [Sovaldi] in December 2013, an NS5B inhibitor developed by Gilead. Sofosbuvir is safe and potent first in class nucleoside

inhibitor of NS5B potency with pan-genotypic activity against HCV genotypes 1, 2, 3 and 4 [9]. Simeprevir [Olysio] an NS3/4A protease inhibitor was also launched in 2013. Since then many combination therapies involving NS3 protease inhibitors, NS5A inhibitors, and NS5B inhibitors were approved by U. S. FDA. Hepatitis C therapies launched from 2014 to till date were furnished in Table 1 [10].

Table 1: FDA approved drugs for hepatitis C launched since 2014

\begin{tabular}{|c|c|c|c|c|}
\hline Year & Brand name & Drug name & Manufacturer & Genotype [SV] \\
\hline 2014 & Sovaldi/Olysio/RBV & Sofosbuvir/Simeprevir/RBV & Janssen & Genotype 1 [Up to $92 \%$ ] \\
\hline 2014 & Harvoni & Sofosbuvir/ledipasvir & Gilead & Genotype $1,4,5,6$ [Up to $100 \%$ ] \\
\hline 2014 & VIEKIRA PAK & $\begin{array}{l}\text { Ombitasvir, Paritaprevir/Ritonavir, Dasabuvir } \\
\text { with/without Ribavirin }\end{array}$ & AbbVie & Genotype 1 [Up to $100 \%]$ \\
\hline 2015 & Daklinza & Daclatasvir for use with Sofosbuvir & Bristol-Myers Sqibb & Genotype 3 [Up to 98\%] \\
\hline 2015 & Technivie & Ombitasvir, Paritaprevir and Ritonavir plus Ribavirin & AbbVie & Genotype 4 [Up to $100 \%$ \\
\hline 2016 & ZEPATIER & Elbasvir/Grazoprevir & Merck & Genotype 1,4 [Up to $100 \%$ ] \\
\hline 2016 & Epclusa & Sofosbuvir/Velpatasvir & Gilead & Genotype 1-6[95\%] \\
\hline
\end{tabular}

But the high cost of these medications limits their use, and there still exist a need for cost-effective therapies, therapeutic agents for Hepatitis C patients with liver cirrhosis or carcinoma, and most important anti-HCV agents with potent activity against genotype 3 which is the second most predominant HCV variants. The purpose of this review is to discuss the reported active site and the allosteric site directed NS5B inhibitors identified till date.

\section{Hepatitis C virus}

Hepatitis $\mathrm{C}$ virus is small, spherical, enveloped, the hepatotropic RNA virus that causes acute and chronic hepatitis in humans. HCV belongs to Flaviviridae family. HCV is classified into seven different genotypes $(1,2,3,4,5,6$ and 7$)$ which differ in nucleotide sequentially by $30 \%$; these genotypes are further classified into 
different subtypes [a, b, c, d... etc.] That differs in nucleotide sequence by $20-25 \%$. Different HCV genotypes also differ in worldwide distribution, transmission and disease progression [11]. It has+Ve stranded RNA as the genome. HCV genome is almost 9.6 $\mathrm{KB}$ in length with an open reading frame (ORF) and encodes a polypeptide of 3000 amino acid residues long; this polypeptide is cleaved by host protease and HCV protease into 10 structural and non-structural components [8]. The structural proteins, namely $\mathrm{C}$ (Core); E1 (envelope protein 1); E2 (Envelope protein 2) are located at the amino end, while the nonstructural proteins NS2, NS3, NS4A, NS4B, NS5A, NS5B are located at the carboxyl-terminal end. The p7 protein [ion channel or viroporin] is located at the junction of structural and non-structural proteins. All these proteins assemble to form a replication complex on the host membrane called as membrane hub and promote replication of the viral genome [12]. Among them NS5B, a non-structural trans membrane protein is considered as an important and attractive target for drug development, since it plays a key role in replication of the HCV genome and host lacks this function equivalent.

\section{NS5B RNA-dependent RNA polymerase}

NS5B is the HCV RNA-dependent RNA polymerase that catalyzes the polymerization of ribonucleoside triphosphates (rNTP) during viral RNA replication. It is 591 amino acids long and the last 21 amino acids at the C-terminal end function as a cell membrane anchor and are hydrophobic in nature. Therefore NS5B is classified under membrane protein, termed as "tail-anchored proteins"[13, 14]. NS5B can be expressed both in the full-length form and truncated form. The structure of NS5B resembles the shape of an encircled right hand containing 3 domains, the thumb domain (residues 371-563), finger domain (residues 1-187 and 228-286) and the palm domain (residues188-227 and 287-370) [8].

The thumb domain and finger domain are bridged by two loops, namely the $\Delta 1$ loop and $\Delta 2$ loop. These two loops facilitate the NS5B to maintain its closed conformation which is required for nucleic acid binding and for cramping movement of the enzyme across the RNA template during elongation[8]. NS5B has allosteric sites in addition to the active site, namely palm I [palm domain near the active site], palm II (partially overlapping palm I and towards the active site), thumb I (thumb domain near the fingertips), thumb II (the outer surface of the thumb domain) (

Fig. 1). There is also an allosteric rGTP (riba guanosine triphosphate) binding site at the interface between fingers loop and thumb domain which allows alternative interactions between the two domains. The GTP binding is required for RNA replication as it stimulates RNA synthesis by enhancing the initiation step $[15,16]$.

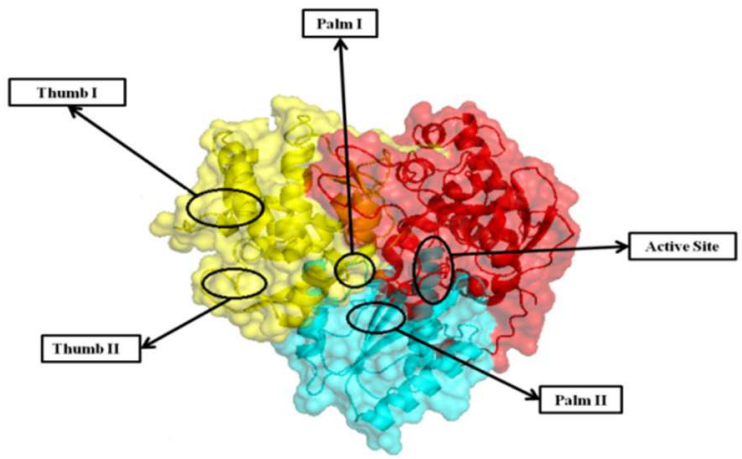

Fig. 1: Overall structure of NS5B polymerase [PDB ID: 1QUV]. The structure of NS5B highlights the fingers domain [red], palm domain [cyan] and thumb domain [Yellow]

\section{Mechanism of RNA synthesis by NS5B}

HCV replication occurs in close proximity to intracellular membranes. Early during the infection, HCV induces the formation of a double-membrane vesicle which emerges as protrusions of the endoplasmic reticulum. These vesicles form the membranous web that can be used as replication site [17, 18]. NS5B synthesizes complementary -Ve stranded RNA from +Ve stranded RNA template. RNA synthesis with NS5B can occur either by de novo initiation-or primer extension [Self primer] [8]. NS5B uses divalent metal ions as co-factors such as magnesium or manganese for RNA synthesis.

De novo initiation involves recognition of the 3'end of template RNA by NS5B and synthesis of RNA without the use of a primer.

Primer extension involves elongation of the primer along the length of the template, which corresponds to the elongation step in the due novo initiation. The primer is self-primer [3' end of the template RNA folds back intra-molecularly]. Since NS5B lacks the proofreading function. As a result, there is a high rate of error-prone replication leading to mutations [8].

\section{NS5B inhibitors}

There are several classes of NS5B inhibitors that target the active site and the allosteric sites of the enzyme thus inhibiting HCV replication. NS5B inhibitors are broadly categorized into Nucleoside analogues (bind to active site) and Non-nucleoside analogues (bind to allosteric sites)[19].

\section{Nucleoside/Nucleotide analogues (NI)}

Nucleoside/Nucleotide inhibitors (NI) target the highly conserved active site of the polymerase and terminate the RNA synthesis by getting incorporated into the RNA chain in lieu of naturally occurring nucleotide triphosphates (NTP's), hence they are also called chain terminating inhibitors $[8,20]$. The ionic nature of the phosphate group present in nucleotides prevents them from penetrating into the cell membrane; hence they are delivered as uncharged nucleosides. Once delivered these nucleosides are phosphorylated to 5'-triphosphate form [active form) by cellular kinases, where the formation of the monophosphate form is the rate limiting step [21, 22]. Many of these compounds have progressed to clinical trials and they act in synergy with interferon and Ribavirin combination.

\section{Purine nucleoside inhibitors}

Researchers at the Merck Research Laboratory designed 2'- $\beta$ methylated analogues by modifying the Ribose moiety of a nucleoside, namely 2'-C-Methyladenosine (1) and 2'-Cmethylguanosine (2) and tested their anti-HCV activity [23]. 2'C-Methyladenosine displayed potent activity against NS5B ( IC $_{50}$ $=1.9 \mu \mathrm{M})[24,25]$, but its efficacy was hampered by poor oral bioavailability and stability. In order to improve the efficacy Hecker et al. From Merck developed 4-pyridyl pro-drugs which showed high aqueous solubility, bioavailability, and stability.

Several hetero based modified analogues of 2'-C-Methyladenosine were also developed with reduce polarity and good cell permeability, but they showed poor stability. Hence the focus was moved towards the development of phosphoramidate analogues to enhance stability. Compound 3 was identified as most potent among the series with replicon $\mathrm{EC}_{50}$ of $0.26 \mu \mathrm{M}$ and is a potential candidate for further development [26].

2'-C-methylguanosine (2) was active against NS5B with IC $_{50}$ of $0.13 \mu \mathrm{M}$ and replicon $\mathrm{EC}_{50}$ of $3.5 \mu \mathrm{M}$; it also showed enhanced bioavailability [27]. Structure-activity relationship [SAR] studies revealed that $\beta$-orientation of a methyl group at 2 -C position is required for the activity.

Either alpha-orientation of the methyl group or movement of a methyl group to 3' position diminishes the activity [24]. Several heteros based modified analogues of 2'-C-methylguanosine such as 7-deazaguanosines, 2'methyl-6-0-methyl-guanosine [28] were mentioned in the literature but none of them have been progressed to further development. 

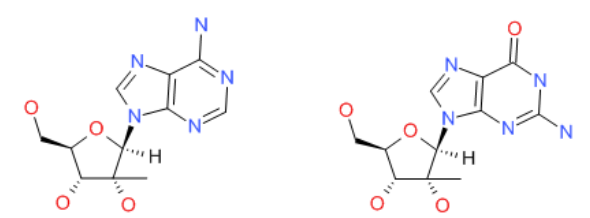

2'-C-Methyladenosine [1] 2'-C-methylguanosine [2]

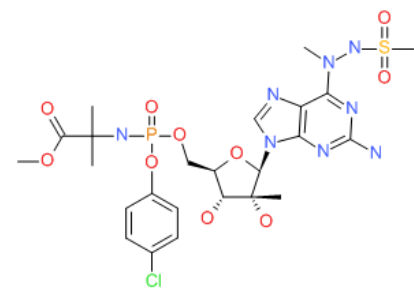

Phosphoramidate analogue [3]

\section{Pyrimidine nucleoside inhibitors}

Idenix discovered 2'-C-Methylcytidine (4) which displayed potent anti-HCV activity with $\mathrm{EC}_{50}$ of $0.26 \mu \mathrm{M}$ in the replicon assay $[29,30]$. But the efficacy of 2'-C-Methylcytidine was hampered by poor oral bioavailability and in order to improve the efficacy Pierra et al. developed 3'-O-L-valinyl ester analogue valopicitabine (NH283) (5) [31]. NH283 reduced viral load when given alone or in combination with pegylated interferon, but its development was discontinued due to gastrointestinal side-effects [32]. A series of 3'deoxyribonucleosides have also been described as chain terminators, among them 3'-deoxycytidine displayed submicromolar potency in viral replicon assay $[29,33]$. However, these 2'-C-methyl ribonucleosides are not effective against the S282T mutant, so 2'-0methyl ribonucleotides were developed and among them 2'-0methylcytidine (6) showed no difference in activity against the mutant and the wild-type [25].<smiles>C[C@]1(O)[C@H](O)[C@@H](CO)O[C@H]1n1ccc(N)nc1=O</smiles>

2'-C-methylcytidine [4] Valopicitabine [5]<smiles>CC(C)C(N[ClH+])C(=O)O[C@H]1C(CO)OC(N2C=CC([NH3+])NC2=O)[C@]1(C)O</smiles>

2'-O-methylcytidine [6]
Klumpp et al. At Roche identified R1479 (4'-azidocytidine) as an NS5B inhibitor through targeted screening of nucleotide library. R1479 displayed potent activity in sub-genomic replicon assay (IC 50 $=1.28 \mu \mathrm{M}$ ) but showed no effect in cytotoxicity assay[34] and also showed limited cell permeability and poor bioavailability. Further, R1626 was developed as a prodrug for R1479 (4'-azidocytidine) which displayed potent anti-HCV activity with $\mathrm{IC}_{50}$ of $1.28 \mu \mathrm{M}$ in HCV subgenomic replicon system and had no effect on cell viability or proliferation of Huh-7 cells [35, 29].

4'-azidouridine (7) the corresponding analogue of R1479 [4'azidocytidine] was also found to be inactive in inhibiting $\mathrm{HCV}$ replication. Later, Perrone et al. developed permeable membrane phenyl ProTide form of 4'-azidouridine (8) which showed good antiviral activity $\left[\mathrm{EC}_{50}=0.61 \mu \mathrm{M}\right.$ ). Naphthyl ProTide form (9) was more active than the phenyl counterpart in inhibiting HCV replication[34]. Meanwhile, other pyrimidine analogues such as beta-D-2'-deoxy-2'-fluoro-2'-C-methylcytidine (PSI 6130)[33], N4hydroxycytidine [36] and 2'-fluororibonucleosides[37] also appeared in literature as anti-HCV agents. PSI-6130 is a highly potent antiNS5B agent and is effective against the S282T mutant. Currently, RG7128 the prodrug of PSI-6130 is in Phase 3 and is the first agent to show a broad genotypic coverage [33].

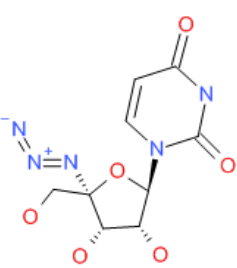

4'-azidouridine [7]

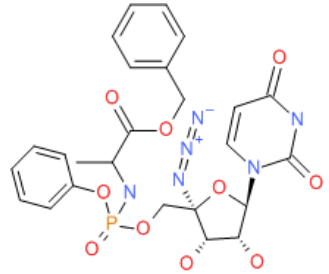

Phenyl ProTide form [8]

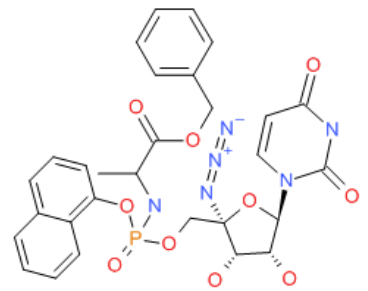

Naphthyl phosphoramidate form [9]
Sofosbuvir (a prodrug of 2'-F-2'-C-methyluridine monophosphate), developed by Gilead Sciences, has been shown to be effective across $\mathrm{HCV}$ genotypes $1 \mathrm{~b}, 2 \mathrm{a}, 3 \mathrm{a}$ and $4 \mathrm{a}\left(\mathrm{IC}_{50}=0.7-2.6 \mu \mathrm{M}\right)$ and also provided a genetic barrier to resistance [38, 39]. In a randomized, open-label study, Sofosbuvir showed sustained virologic response in patients infected with HCV genotype 1, 2 and 3 when given in combination with Daclatasvir, an NS5A inhibitor[40]. Jonckers et al. identified a series of phosphoramidate prodrugs of 2'-deoxy-2'spirooxetane ribonucleosides. These prodrugs showed antiviral activity in HCV replicon assay (Huh-7 cells) with an $\mathrm{EC}_{50}$ value ranging from 0.2 to $>98 \mu \mathrm{M}$, but failed to show potency in cytotoxicity assay [41].

Resistant mutations to NI include S282T, S96T, and N142T; of these S282T confer resistance to Sofosbuvir, 2'-C-methylcytidine and 2'-Cmethyladenosine while S96T and N142T confer resistance to 4'azidothymidine (R1479). The $\mathrm{S} 282$ residue is in close proximity to the residues binding at NTPi (initiation nucleotide) [42]. Hence it is clear that NTP binding site is altered during de novo initiation of RNA synthesis and elongation. 


\section{Miscellaneous nucleoside analogues}

These are the nucleoside mimics who do not possess either a Purine or a Pyrimidine nitrogenous base. Ribavirin is the best example of this class. In an attempt to develop a more potent analogue of Ribavirin, Witkowski et al. discovered Taribavirin [viramidine] [43]. Taribavirin targets the liver and has a better safety profile [less likely to cause anemia] than Ribavirin, therefore Taribavirin is considered as a potential candidate for further development and is currently in Phase 3 clinical trials [44]. However, in the ViSER1 study taribavirin given at $600 \mathrm{mg}$ BID, was able to improve survival rates in only $44 \%$ of patients and is inferior to Ribavirin which improved survival rates in $55 \%$ of patients [45]. Other miscellaneous nucleoside analogues include acyclic triazole analogues synthesised by Zhu $\mathrm{R}$ et al.[46], pyrrolopyrimidines designed at Valeant [47], alpha-gamma-diketo acids [48] but none of them had entered clinical trials.

M. Emilia Di Francesco et al. designed a series of nucleoside inhibitors bearing a 7-heterocyclic substituted 7-deaza-adenine nucleobase. The most potent of this series is the 1,2, 4-oxadiazole analogue which showed potent anti-viral activity in in vitro and in vivo[49]. Manfroni et al. reported that one of the 6-aminoquinolone derivatives 6-amino-7-[4-[2-pyridinyl]-1-piperazinyl]quinolone showed good anti-HCV activity in an enzymatic assay $\left(\mathrm{IC}_{50}=0.069\right.$ $\mu \mathrm{M}$ ) and replicon assay $\left[\mathrm{EC}_{50}=3.03 \mu \mathrm{M}\right.$ ) with low cytotoxicity [50]. The nucleoside inhibitors currently in different phases of development are given in Table 2.

Table 2: Nucleoside inhibitors in the market and under investigation

\begin{tabular}{lll}
\hline Molecule & Clinical phase & Company \\
\hline GS-7977 [Sofosbuvir] & Launched & Gilead \\
VX-135 & Phase 2 & Vertex Pharmaceuticals \\
ACH-3422 & Phase 1 & Achillion \\
PSI-938 & Discontinued & Gilead \\
RG7128 [Mericitabine] & Discontinued & Roche \\
IDX21437 [MK 3682] & Phase 2 & Idenix/Merck \\
IDX184 & Discontinued & Idenix \\
PSI-7851[Isomer of Sofosbuvir] & Discontinued & Pharmasset \\
TMC649128 & Discontinued & Medivir and Tibotec \\
GS-6620 & Phase 1 & Gilead \\
BCX5191 & Discontinued & Biocryst \\
Valopicitabine & Discontinued & Idenix/Novarties \\
\hline
\end{tabular}

*Clinical phase details of all compounds are captured from Adisin sight

GS-6620 demonstrated potent activity in phase 1 clinical study but showed high pharmacokinetic and pharmacodynamic variability [51, 52]. VX-135 in combination with Daclatasvir was well tolerated in HCV genotype 1 infected patients but showed a moderate SVR in a phase-2 study [NCT01842451]. ACH-3422 showed pan-genotypic activity in vitro and was well tolerated in phase- 1 randomized double-blind study [53, 54]. TMC649128 developed by Tibotec pharmaceuticals entered phase $1 \mathrm{~b}$ trials where safety, tolerability, pharmacokinetics and antiviral activity of the compound are evaluated [55]. IDX21437 a uridine nucleotide analog generated high triphosphate levels and showed potent pan-genotypic activity and is currently being evaluated in phase II trials [NCT02332707] [56].

\section{Non-nucleoside analogues (NNI)}

Non-nucleoside analogues are the alternative means for targeting viral polymerases. These analogues target al. losteric sites of NS5B and cause change in the conformation of the active site, thereby inhibiting the initiation phase of the RNA synthesis. The allosteric sites on the HCV polymerase namely Site I is located in the interface of the finger loop ( $\Delta 1$ loop) and thumb domain, Site II is located in the thumb region beneath the site I, site III is in the template channel region in the palm domain and includes 'primer-grip site' and Betaloop, Site IV located near the active site in the palm region. There is also another allosteric site located in the finger loop i.e. Site V.

\section{Site I [Thumb I]}

Site I is at the upper section of the thumb domain which is $30 \AA$ away from the active site and is at the junction of the thumb and the finger

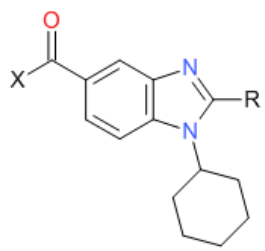

10, $\mathrm{X}=\mathrm{OH}, \mathrm{R}=2$-pyridyl, $\mathrm{IC}_{50}=4.3 \mu \mathrm{M}$ 11, $\mathrm{X}=\mathrm{OH}, \mathrm{R}=3$-furyl, $\mathrm{IC}_{50}=1.6 \mu \mathrm{M}$ domain [11]. The site I also overlap with the allosteric GTP binding site. When the inhibitor binds to site I, it displaces the $\Delta 1$ loop and brings a change in the conformation of the enzyme thereby disrupting the inter-domain communication. This change in conformation prevents the formation of the NS5B-RNA complex, thereby inhibiting RNA synthesis in an NTP non-competitive manner. But the compounds targeting this site do not inhibit elongation phase of RNA synthesis and they also do not have any effect on the performed NS5B-RNA complex [57, 58]. Amino acid substitutions at P495, P496 and V499 with Ala, Leu, and Ser respectively render resistance to this class of inhibitors. Substitution at P495 position confers a high level of resistance to inhibitors and substitution at P496 and V499 residues renders low-level of resistance [58].

\section{Benzimidazoles}

Benzimidazoles identified by Boehringer Ingelheim inhibited NS5B at low micromolar $\mathrm{IC}_{50}$ values [8,59-61]. Using high-throughput parallel synthetic techniques, 1, 2-disubstituted benzimidazole 5carboxylic acid scaffold was identified as the minimum core for biological activity [62]. Ishida et al. identified compound $\mathbf{1 0}$ of the benzimidazole class with $\mathrm{IC}_{50}$ value of $4.3 \mu \mathrm{M}$ in an enzyme inhibition assay [63]. Removal of the $\mathrm{N}$-cyclohexyl in benzimidazole scaffold led to a complete loss in the activity. Hence, a six-membered ring at the $\mathrm{N} 1$ position is a significant fragment and optimally fits to the hydrophobic pocket [64]. Replacement of 2-pyridyl part of $\mathbf{1 0}$ with 2-furyl led to a more potent analogue compound $11\left(\mathrm{IC}_{50}=1.6 \mu \mathrm{M}\right)$.

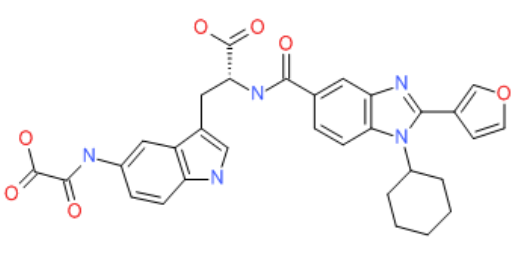

12, $\mathrm{IC}_{50}=0.008+/-0.002 \mu \mathrm{M}$ 
Beaulieu et al. later reported that modifications to the right-hand side of the molecule [at C2 carbon] lead to 800-fold increase in potency. The most potent of them is compound 12 with $\mathrm{IC}_{50}$ of $0.008+/-0.002 \mu \mathrm{M}[65]$. Elongation of the alkyl chain from benzyl did not influence the potency. Hirashima et al. reported a series of benzimidazole derivatives with biphenyl substituent at C2 position[66]. Intense modification led to identification of a potent analogue 13 which was effective against genotype 1 a (IC50 = 62
$\mathrm{nM})$, genotype $1 \mathrm{~b}\left(\mathrm{IC}_{50}=17 \mathrm{nM}\right)$ and genotype $3 \mathrm{a}\left(\mathrm{IC}_{50}=61 \mathrm{nM}\right)$. Promising pharmacokinetic (PK) parameters and good safety profiles of compound 13 (JTK-109) led it to its clinical development as an anti-HCV agent. Vaishali Patil et al. designed a series of benzimidazole derivatives by introducing alkyl group at N3 and benzoxy phenyl group at C2 positions of benzimidazole nucleus, of which potent compounds inhibited NS5B activity by $24.2 \%$ at 100 $\mu \mathrm{M}$ concentrations [67].

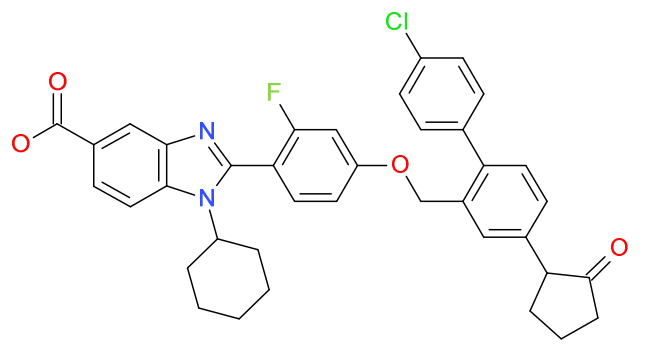

13 [JTK-109], $\mathrm{IC}_{50}=17 \mathrm{nM}$

Weidlich et al. identified Candesartan cilexetil as specific NS5B inhibitor through machine learning approach. Candesartan is an angiotensin II receptor blocker and is currently used to treat hypertension. Candesartan cilexetil, when tested in in vitro for antiNS5B, showed potency in the micromolar range. Preliminary docking results indicated that replacement of benzyl ring in benzimidazole with thiazine-1, 1-dioxide can improve the activity of Candesartan cilexetil [68].

\section{Indoles}

In order to improve the potency of benzimidazoles, Beaulieu et al. replaced the benzimidazole core of inhibitors with a more lipophilic indole group. The indoles showed more than 30 fold improvement in cell-based replicon assay [69]. Harper et al. reported a series of indole- $\mathrm{N}$-acetamide derivatives and determined their anti-HCV potency in Huh-7 cells [70]. Among them morpholine acetamide analogue (14) exhibited good potency in replicon assay $\left(\mathrm{IC}_{50}\right.$ of $11+/-2 \mathrm{nM})$ and cell based assay as well $\left[\mathrm{EC}_{50}=0.3+/-0.1 \mu \mathrm{M}\right)$ with less cytotoxicity $\left[\mathrm{CC}_{50}=>50 \mu \mathrm{M}\right)[70]$.

A series of indole derivatives were developed by replacing C-6 carboxylic acid group [71]. All the compounds in the series possess activity in nanomolar range against NS5B and micromolar to submicromolar activity in replicon assays, the most potent being Compound 15 with $\mathrm{IC}_{50}=4 \mathrm{nM}$ and $\mathrm{EC}_{50}=0.12 \mu \mathrm{M}$.

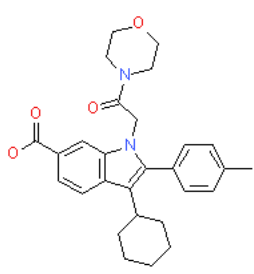

14, $\operatorname{IC50}=11+/-2 \mathrm{nM}$

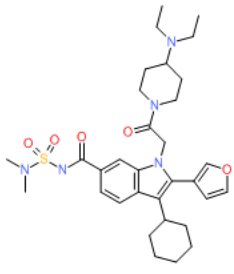

$15, \mathrm{IC} 50=4 \mathrm{nM}$ $\mathrm{EC} 50=0.12 \mu \mathrm{M}$

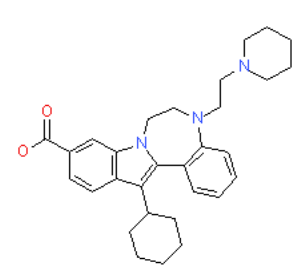

16, IC50 $=0.0090 \mu \mathrm{M}$
Ikegashira et al. developed a series of 6,7-dihydro-5Hbenzo[5,6][1,4]diazepino[7,1-a]indoles as NS5B inhibitors [72]. The 6,5 -bicyclic core and the C-2 ring were bridged to get a potent compound. Among them compound $\mathbf{1 6}$ was found to be a potent analog with an $\mathrm{IC}_{50}$ value of $0.0090 \mu \mathrm{M}$ [72]. Venkatraman et al. described a series of analogues based on tricyclic indole scaffold and tested them for anti-viral activity. It was found that some of these compounds showed potent activity against NS5B genotype 1b in the biochemical and cellular assay, but showed modest PK in rats. Later ester prodrugs of these compounds were designed to improve the PK [73].

In an attempt to improve the aqueous solubility of indoles, David McGowan et al. designed a series of 1,6 and 2,6 macrocyclic bridging indoles by connecting tether to either the indole nitrogen or phenyl ring in the C2 position of the central indole core [74]. Further optimizations of these macrocyclic indoles generated potent allosteric inhibitors targeting the finger loop domain and eventually lead to the discovery of TMC647055. TMC647055 showed nanomolar potency in the cellular assay, limited toxicity and promising PK properties in rats and dogs and is currently being evaluated in clinical $[75,76]$. Velázquez et al. reported the synthesis of 3, 4-dihydrofuranoindoles which showed inhibitory activity against NS5B with $\mathrm{IC}_{50}$ values in the range of 6-15 $\mathrm{nM}$ [77].

Gentles et al. through analogue based drug design optimized cyclopropyl-fused indole benzazepines and in the process identified BMS-791325 which showed potent anti-NS5B activity, good safety and PK properties. BMS-791325 also showed promising results clinically when given in combination with Daclatasvir (NS5A inhibitor) and Asunapevir [NS3 inhibitor] [78].

\section{Quinoxalines}

Rong et al. identified compound 17 via high throughput screening of compound library. Optimization of 17 resulted in more potent analogue (compound 18) with an $\mathrm{IC}_{50}$ value of $0.69 \mu \mathrm{M}$ in NS5B inhibition assay [79].

\section{Thieno [3,2-b]pyrroles}

Ontoria et al. through replacement of 6, the 5-bicyclic core of benzimidazole developed trisubstituted azaindoles and were tested in enzyme inhibition and replicon assay. The regioisomeric thieno [3, 2-b] pyrrole 20a is nearly as potent as 19 in enzyme inhibition 
assay. However compound 20a was less active in the replicon assay $\left[\mathrm{EC}_{50}=11.2 \mu \mathrm{M}\right)$ as compared to 19 and introduction of an acetamide group led to a 4 fold improvement in replicon activity $\left[20 \mathrm{~b}, \mathrm{EC}_{50}=2.9 \mu \mathrm{M}\right)[80]$.<smiles>O=C(O)c1ccc2nc(-c3ccc(F)cc3)c(-c3ccc(F)cc3)nc2c1</smiles>

$\mathbf{1 7}, \mathrm{IC}_{50}=5.5 \mu \mathrm{M}$<smiles>O=C(O)/C=C/c1ccc(NC(=O)C2(NC(=O)c3ccc4nc(-c5ccc(F)cc5)c(-c5ccc(F)cc5)nc4c3)CCC2)cc1</smiles>

18, $\mathrm{IC}_{50}=0.69 \mu \mathrm{M}$

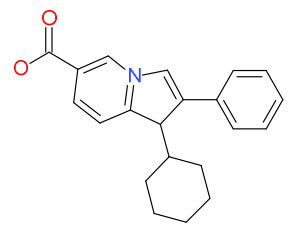

$19, \mathrm{IC}_{50}=0.094 \mu \mathrm{M}$<smiles>O=C(O)c1cc2[nH]c(-c3ccccc3)c(C3CCCCC3)c2s1</smiles>

$20 \mathrm{a}, \mathrm{IC}_{50}=0.066 \mu \mathrm{M}$

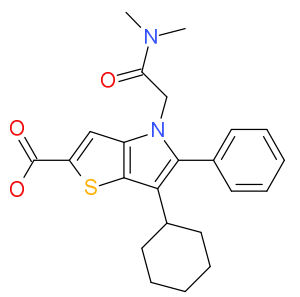

$20 \mathrm{~b}, \mathrm{IC}_{50}=0.058 \mu \mathrm{M}$

\section{Coumestan derivatives}

Coumestans belong to the flavonoid class of phytoestrogens. Based on the structure-activity relationship investigations on wedelo-lactone and four synthetic coumestan derivatives, it was proposed that these compounds serve as potent anti-HCV agents[81]. Wedelolactone and LQB34 ( $\mathrm{IC}_{50}$ of $18.5 \mu \mathrm{M}$ ) were active in the NS5B enzyme inhibition assay. The thumb I NNIs that are currently in different phases of development are given in Table 3.

Table 3: Non-nucleoside thumb I inhibitors

\begin{tabular}{lll}
\hline Molecule & Clinical phase & Company \\
\hline Beclabuvir [BMS-791325] & Phase 3 & Bristol-Myers Squibb Company \\
MK-3281 & Discontinued & Merck \\
BI 207127 [Deleobuvir] & Discontinued & Boehringer Ingelheim \\
TMC647055 & Phase 2 & Janssen \\
BILB 1941 & Discontinued & Boehringer Ingelheim \\
\hline
\end{tabular}

*Clinical phase details of all compounds are captured from Adisinsight

BMS-791325 inhibited NS5B from HCV genotype 1, 3, 4, and 5 with $\mathrm{IC}_{50}$ value of $<28 \mathrm{nM}$ and showed a $\mathrm{EC}_{50}$ value of $3 \mathrm{nM}$ and $6 \mathrm{nM}$ against genotype $1 \mathrm{a}$ and $1 \mathrm{~b}$ respectively in replicon assay [82]. However, amino acid substitutions at P495 conferred resistance to the compound [83]. BMS-791325 in combination with daclatasvir [DCV], Asunapevir (ASV) showed a substantial viral response in 94 $\%$ of treatment-naive HCV patients [84] and is currently in Phase III trials [NCT02098616]. MX-3281 showed potent anti-HCV activity against genotype $1 \mathrm{a}, 1 \mathrm{~b}$ and $3 \mathrm{~b}$ [85]. But in clinical studies, MX-3281 monotherapy (800 mg BID for $7 \mathrm{~d}$ ) was effective only against genotype 1b [86]. BI207127 developed by Boehringer-Ingelheim was tested in combination with faldaprevir and Ribavirin. Data from an SOUND-C3 study showed that the triple combination gave 95\% survival rate in genotype $1 \mathrm{~b}$ patients [87]. Currently, phase III trials are being completed for BI207127 in combination with faldaprevir and Ribavirin in chronically infected HCV GT1b treatment-naive patients [NCT01728324]. However, in a phase III study it was found that amino acid substitutions $\mathrm{P} 495 \mathrm{~L} / \mathrm{S} / \mathrm{T}$ were more common which lead to viral relapse hence the development of BI207127 was halted [88]. TMC64705, an indole derivative showed cross-genotypic activity in in vitro replicon assay, but amino acid residues L392 and P495 were associated with resistance [89]. Findings from Phase 1b suggested that TMC647055 in combination with NS3 inhibitor simeprevir was well tolerated and showed potent antiviral activity [76]. Phase II trial evaluating the safety, tolerability, efficacy and pharmacokinetic profiles of TMC647055 in combination with Samatasvir, simeprevir and JNJ56914845 (NS5A inhibitor) in HCV genotype $1 \mathrm{a}$ and $1 \mathrm{~b}$ infected patients was completed [NCT01852604]. BILB 1941, when given as monotherapy for $5 \mathrm{~d}$, demonstrated potent antiviral activity, but its development was limited by gastrointestinal tolerance [90].

\section{Site II [Thumb II]}

The binding pocket of site II inhibitors is a shallow hydrophobic pocket situated at the base of the thumb domain [91]. Inhibitors binding at this site also interfere with interactions between the finger loop and the thumb domain thereby preventing the enzyme from adopting a closed conformation. Mutations at this site, namely L419M, M423T render high-level resistance to Site II inhibitors.

\section{Thiazolone derivatives}

Yan et al. identified Compound $\mathbf{2 1}$ as an allosteric inhibitor of NS5B $\left(\mathrm{IC}_{50}=3.0 \mu \mathrm{M}\right)$ by screening the Valeant in-house compound collection [92]. SAR studies of $\mathbf{2 1}$ revealed that replacement of 4fluorophenyl moiety with other aryl substituents was not tolerated [93]. On examination of the binding mode of thiazolones, it was found that the 4-fluorophenyl group occupies a deep hydrophobic pocket defined by the side chains of Leu419, Met423, Tyr477, and Trp528, the $\mathrm{C}==\mathrm{O}$ of thiazolone ring forms hydrogen bond with- $\mathrm{NH}$ of Tyr477, while the lone pair $\mathrm{N}$ makes hydrogen bond with $\mathrm{NH}$ group of Ser 476. Ethyl-furan moiety of the inhibitors binds to the hydrophobic channel defined by Leu419, Met423, Ile482, Val485, Leu489, and Leu497 [93]. 
<smiles>CCc1ccc(/C=C2\SC(N[C@H](C(=O)O)c3ccc(F)cc3)=NC2=O)o1</smiles>

$21, \mathrm{IC50}=3.0 \mu \mathrm{M}$<smiles>COc1ccccc1N1CCN(C(=O)CNc2ccc(S(=O)(=O)NC3=NC(=O)/C(=C/c4ccc(-c5ccccc5)cc4)S3)cc2)CC1</smiles>

22, IC50 = $0.75 \mu \mathrm{M}$
Al-Ansary et al. designed a novel series of thiazolone derivatives by replacing the furan moiety coupled to the thiazolone core with a large spacer and hydrophobic moiety to fill the hydrophobic pocket in the thumb II site and tested this for the anti-HCV activity. The most potent among the tested is compound 22 with $\mathrm{EC}_{50}$ value of $0.75 \mu \mathrm{M}$ in the HCV genotype $1 \mathrm{~b}$ replicon assay [94].

\section{Quinazolin-4-ones}

Beaulieu et al. through structure based drug designing strategy designed $1 \mathrm{H}$-quinazolin-4-one analogue by hybridization of thiazolone and anthranilic acid based inhibitors. These quinazolin-4ones showed potent anti-HCV activities in replicon assays against genotype $1 \mathrm{a}$ and $1 \mathrm{~b}$ with $\mathrm{EC}_{50}$ values of $<200 \mathrm{nM}$ [95].

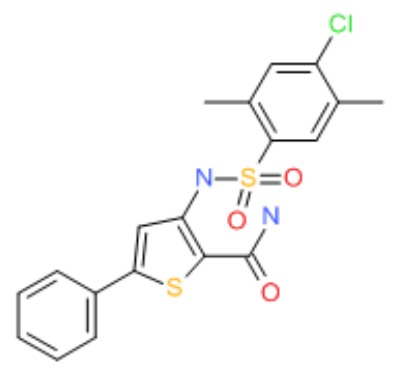

23, IC50 $=14 \mu \mathrm{M}$

\section{Thiophene-2-carboxylic acid derivatives}

Compounds based on the thiophene scaffold were originally identified by Shire Biochem Inc., as binding to NS5B in the thumb domain and inhibiting its activity [96]. Compounds of this class are hydrophobic, and bind to the hydrophobic binding site [site II] in the enzyme, forming interactions with L419, M423, L474, and W528 residues.

Researchers at Shire Biochem discovered thiophene-2carboxamide (23) as an allosteric inhibitor of the NS5B polymerase during a screening campaign $[97,98]$. Optimization of compound 23 generated compound 24 with improved potency.

\section{Phenylalanines}

Wang et al. had identified $\mathrm{N}, \mathrm{N}$-disubstituted phenylalanine analogues as a novel class of NS5B inhibitors. Compound 25 with $\mathrm{IC}_{50}$ value of $5.7 \mu \mathrm{M}$ was the more potent in the series. This lead compound provided a good starting point for the optimization

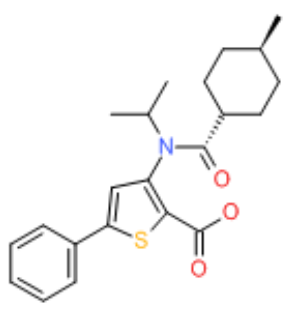

24, $\operatorname{IC} 50=1.5 \mu \mathrm{M}$

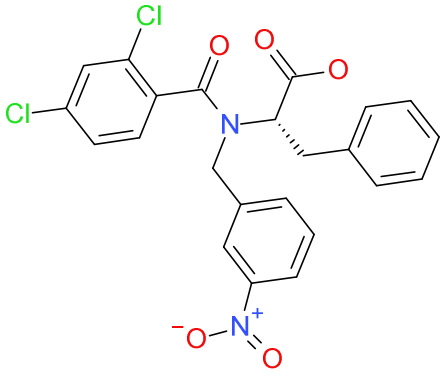

$25, \mathrm{IC}_{50}=5.7 \mu \mathrm{M}$

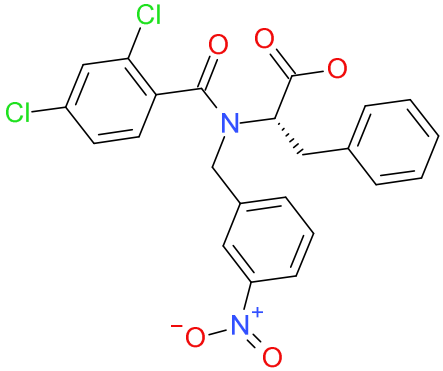

$26, \mathrm{IC}_{50}=0.7 \mu \mathrm{M}$

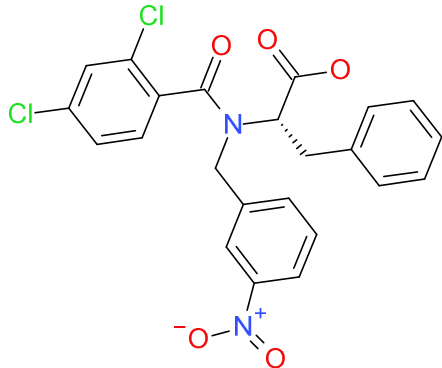

$27, \mathrm{IC}_{50}=0.8 \mu \mathrm{M}$

\section{Pyranoindoles}

Pyranoindoles that putatively bind at Site II inhibit the transition between initiation and elongation stage of RNA synthesis[101]. Researchers from Wyeth have done high throughput screening [HTS] of the various compound libraries. The effort culminated in the identification of pyran oxindole 28 with $\mathrm{IC}_{50}$ value of $3.0 \mu \mathrm{M}$ in NS5B inhibition assay[102]. study [91, 99]. Optimization of compound 25 by introducing nitro and cyano groups at meta position generated more potent analogues 26 and 27 with $\mathrm{IC}_{50}$ values of 0.7 and $0.8 \mu \mathrm{M}$ respectively, and retained selectivity against human DNA polymerases $\alpha, \beta$, and $\gamma\left(\mathrm{IC}_{50}>50 \mu \mathrm{M}\right)[100]$. 


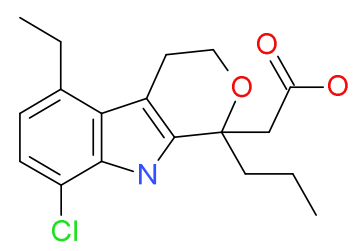

$28, \mathrm{IC}_{50}=3.0 \mu \mathrm{M}$

28a $[R], \mathrm{IC}_{50}=2.0 \mu \mathrm{M}$

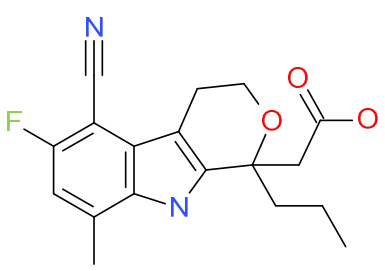

$29, \mathrm{IC}_{50}=0.12 \mu \mathrm{M}$ 29a [R], IC $\mathrm{I}_{50}=0.08 \mu \mathrm{M}$<smiles>CCCC1(CC(=O)O)OCCc2c1[nH]c1c(C)c(OC[C@H](C)n3cccn3)cc(C#N)c21</smiles>

$30, \mathrm{IC}_{50}=0.003 \mu \mathrm{M}[\mathrm{BK}]$ $\mathrm{IC}_{50}=0.003 \mu \mathrm{M}$ [BB7]

\section{Dihydro pyranones}

Hui Li. et al. by identified dihydropyrone 31 high throughput screening of in-house compound libraries which inhibited NS5B

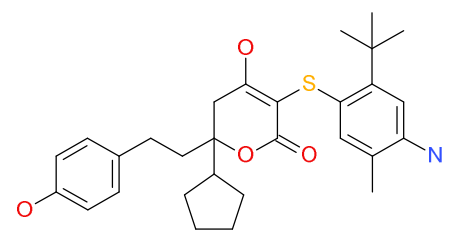

$31, \mathrm{IC}_{50}=0.93 \mu \mathrm{M}$

\section{Thiazolidine-4-one derivatives}

Thiazolidine-4-one scaffold has gained prominence in recent years as it possesses antibacterial [106, 107], antifungal [108, 109], anticonvulsant [110, 111], antituberculosis [112, 113] and anticancer activities. The antiviral activity of thiazolidine-4-one scaffold was emphasized in several studies. Ravindra et al. from HCV genotype $1 \mathrm{~b}$ (BK strain) with $\mathrm{IC}_{50}$ value of $0.93 \mu \mathrm{M}$ [105]. Truncation of compound 31 by removing phenyl at the right-hand side and combined substitutions at para and meta positions of phenyl ring at left-hand side generated compound 32 with good potency [105].

Table 4: Inhibitory activities of 4-thiazolidinone derivatives against NS5BCA21 [genotype 1b]<smiles>[R2]c1cc([R3])c(C2SC([R4])C(=O)N2[Al])c([R])c1</smiles>

\begin{tabular}{|c|c|c|c|c|c|c|}
\hline Compound & Ar & R1 & R2 & R3 & R4 & \%inh \\
\hline 33 & Pyridin-2-yl & $\mathrm{H}$ & $\mathrm{F}$ & $\mathrm{H}$ & $\mathrm{H}$ & $98+/-6.9$ \\
\hline $34 a$ & Pyridin-3-ylmethyl & $\mathrm{Cl}$ & $\mathrm{H}$ & $\mathrm{Cl}$ & $\mathrm{CH} 3$ & $95.6+/-0.8$ \\
\hline $34 \mathrm{~b}$ & Furan-2-ylmethyl & $\mathrm{Cl}$ & $\mathrm{H}$ & $\mathrm{Cl}$ & $\mathrm{CH} 3$ & $97.8+/-0.8$ \\
\hline
\end{tabular}

Küçükgüzel et al. designed a series of 4-thiazolidinone derivatives, of which the potent compound inhibited NS5B with an IC50 value of $5.6 \mu \mathrm{M}$. Molecular modeling studies revealed the influence of arylidene moiety on enzyme activity [115].

\section{Anthranilic acid derivatives}

Thomas Nittoli et al. identified a lead molecule with $\mathrm{IC}_{50}$ value of 1.6 $\mu \mathrm{M}$ (compound 35), by HTS screening of the Wyeth compound library collection. Further optimization of this molecule resulted in analogues showing micromolar potency against the enzyme and in inhibition of viral replication [116]. The most potent among these analogues is compound 36 with an IC50 value of $0.010 \mu \mathrm{M}$.
In an effort to optimize anthranilic acid based inhibitors Timothy A. Stammers et al. discovered compound 37, which showed good activity against NS5B from genotype $1 \mathrm{~b}$ in the biochemical assay and moderate activity in cell based assay[117].

May MM et al. designed a series of N-phenylbenzene sulphonamides which bind to thumb II allosteric site and showed nanomolar potency against NS5B. Genotype profiling showed the potency of these against HCV genotype 1a and 1b [118].

The thumb II non-nucleoside inhibitors that are currently in different phases of development are given in Table 5 . 
<smiles>O=C(COc1ccc(Cl)cc1)Nc1ccccc1C(=O)O</smiles>

$35, \mathrm{IC}_{50}=1.6 \mu \mathrm{M}$<smiles>CC(=O)c1cc(F)c(Br)cc1OCC(=O)Nc1ccccc1C(=O)O</smiles>

$36, \mathrm{IC}_{50}=0.010 \mu \mathrm{M}$

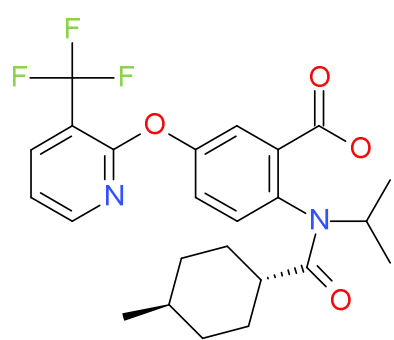

$37, \mathrm{IC}_{50}=0.08+/-0.04 \mu \mathrm{M}$

Table 5: Non-nucleoside thumb II inhibitors

\begin{tabular}{lll}
\hline Molecule & Clinical phase & Company \\
\hline Filibuvir & Discontinued & Pfizer \\
VCH759 & Phase 2 & ViroChemPharma \\
VCH916 & Phase 2 & ViroChemPharma \\
VCH222 [Lomibuvir] & Discontinued & ViroChemPharma \\
GS-9669 [Radalbuvir] & Phase 2 & Gilead \\
\hline
\end{tabular}

*Clinical phase details of all compounds are captured from Adisinsight

Filibuvir developed by Pfizer is a potent inhibitor of NS5B from genotype 1 . In phase, I and II clinical trials, Filibuvir when given as monotherapy or in combination with interferon/Ribavirin for $4 \mathrm{w}$ reduced viral load [119]. But Pfizer halted the development of Filibuvir for business reasons. VCH-759, when given as monotherapy in HCV genotype 1 infected patient, was well tolerated, but had limitations such as gastrointestinal side effects and occurrence of resistant variants [120]. Vertex Pharmaceuticals product VCH-222, when tested in Phase II trials to for anti-viral activity, did not show the promising effect and resistance mutations L419, R422, M423, I482, A486, and V494were common, hence halted for further development [121]. GS-9669 in combination with Sofosbuvir and Ribavirin, reduced viral load in $92 \%$ of patients in a trial involving a small number of patients [122]. Currently, GS-9669 is in phase II and is being evaluated for efficacy in combination with Sofosbuvir and Ribavirin [NCT01984294].

\section{Site III [Palm I]}

Different classes of inhibitors that bind at site III include benzothiadiazides, Acylpyrrolidines, anthranilic acid derivatives, acrylic acid derivatives, indoles and 1, 5-benzodiazepines. These inhibitors bind at a site on the inner thumb/palm domain near the active site and inhibit initiation of RNA synthesis, but do not have any effect on elongation step and already formed enzyme/substrate complex.

\section{Benzothiadiazines}

Benzothiadiazines are an important heterocyclic class of compounds showing beneficial effects in many diseases because of their diverse biological properties, and NS5B inhibitory activity is one among them [122]. Derivatives of benzothiadiazides were initially identified from the GlaxoSmithKline proprietary compound library [123, 124]. Benzothiadiazines inhibited de novo initiation with IC50 values of about 5-10-fold less than those for primer extension [125].

Inhibition with these compounds occurs in a non-competitive manner. These compounds are genotype specific; they have strong activity against $1 \mathrm{a}, 1 \mathrm{~b}$ and $2 \mathrm{a}$ genotypes but weak activity against genotype 3a. Resistant mutations arising in HCV genotype $1 \mathrm{~b}$ replicons after exposure to benzothiadiazines include M414T, C451R, G558R, and H95R [125]. John K. Pratt et al. identified N-1alkyl benzothiadiazines by high throughput screening. These were found to inhibit NS5B polymerase at the initiation step of RNA synthesis. SAR data demonstrated that $\mathrm{N}$-1-alkyl benzothiadiazines with quinolone core and 1, 8-naphthyridone core showed equivalent potencies in inhibition of NS5B polymerase [126].<smiles>Cn1c(=O)c(C2=NS(=O)(=O)c3ccccc3N2)c(O)c2ccccc21</smiles>

Quinolone core<smiles>Cn1c(=O)c(C2=NS(=O)(=O)c3ccccc3N2)c(O)c2cccnc21</smiles>

1,8-naphthyridone core<smiles>[R]n1c(=O)c(C2=NS(=O)(=O)c3ccccc3N2)c(O)c2cccnc21</smiles>

38a, $\mathrm{R}=-\mathrm{CH} 2 \mathrm{CH} 2 \mathrm{CH}[\mathrm{Me}] 2, \mathrm{IC}_{50}=0.069 \mu \mathrm{M}$ $38 \mathrm{~b}, \mathrm{R}=-\mathrm{CH} 2 \mathrm{CH}[\mathrm{Et}] 2, \mathrm{IC}_{50}=0.058 \mu \mathrm{M}$
The nature of hydrophobic functionality at $\mathrm{N} 1$ position impacts the biochemical potency. The compound 38a with unbranched $\alpha$ Carbon at N1 position inhibits NS5B with $\mathrm{IC}_{50}$ of $<0.1 \mu \mathrm{M}$, and branching at alpha-carbon of alkyl group decreases the potency [Compound 38b].

Zhou $\mathrm{Y}$ et al. identified a series of 5-hydroxy-3[2H]-pyridazinone derivatives [39] which bind to the NS5B 'palm' site[127,128]. The addition of linear alkyl fragments with 4-5 carbon atoms at R2 position, 2-thiophene at R1 and-NSO2Me at R3 position of pyridazinones conferred good anti-NS5B and antiviral activities [compound 40, IC $50=<0.01 \mu \mathrm{M}$ ) [129].

John T. Randolph et al. synthesized a series of Isoamyl-substituted Bring aminothiadiazine analogues and neohexyl-substituted B-ring aminothiadiazine analogues and evaluated them for their ability to inhibit NS5B genotype $1 \mathrm{a}$ and $1 \mathrm{~b}[130]$. The primary amine of isoamyl analogue 41 is a potent inhibitor in both enzyme and replicon assays, enantiomer [S-enantiomer] of primary amine 41a is more active in biochemical assay [genotype 1a] as compared to the R-form. 
<smiles>[R3]c1ccc2c(c1)S(=O)(=O)N=C(c1c(O)c([R1])nn([R2])c1=O)N2</smiles><smiles>CC(C)CCC1(N)C(=O)C(C2=NS(=O)(=O)c3cc(NS(C)(=O)=O)ccc3N2)=C(O)c2ccccc21</smiles>

$41, \mathrm{IC}_{50}=12 \mathrm{nM}, \mathrm{EC50}=29 \mathrm{nM}$ 41a, $\mathrm{IC}_{50}=4 \mathrm{nM}, \mathrm{EC50}=37 \mathrm{nM}$<smiles>CC(C)CCn1nc(-c2cccs2)c(O)c(C2=NS(=O)(=O)c3cc(NS(C)(=O)=O)ccc3N2)c1=O</smiles>

40, $\mathrm{IC}_{50}=<0.01 \mu \mathrm{M}$<smiles>Cc1cc(CNC2(CCC(C)(C)C)C(=O)C(C3=NS(=O)(=O)c4cc(NS(C)(=O)=O)ccc4N3)=C(O)c3ccccc32)n(C)n1</smiles>

$42, \mathrm{IC}_{50}=5 \mathrm{nM}, \mathrm{EC} 50=15 \mathrm{nM}$
The isoamyl derivatives described above have low bioavailability and plasma concentration after oral administration.

In an effort to improve the bioavailability and plasma concentration, the isoamyl group is replaced with a neohexyl group.

All the neohexyl analogues showed $\mathrm{IC}_{50}$ value of $<50 \mathrm{nM}$ in NS5B inhibition assay and are equipotent in replicon assay. The most potent of them is 42 .

\section{Benzylidines}

Powers et al. through screening of a small molecule compound library identified compound 43 which is active in inhibiting NS5B $\left(\mathrm{IC}_{50}=1.5 \mu \mathrm{M}\right)[131]$.

SAR investigation on a series of 3-[phenylsulfonyl]-aminorhodanine analogues with variations in the benzylidine ring conferred that unsubstituted benzylidine analogues 44 and 45 are more potent than 43 in enzyme inhibition assay [132].

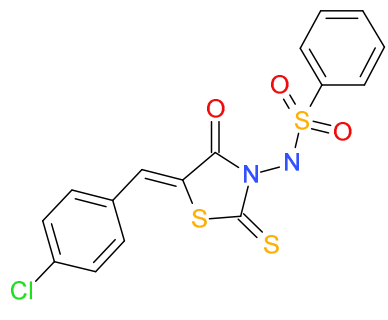

$43, \mathrm{IC}_{50}=1.5 \mu \mathrm{M}$

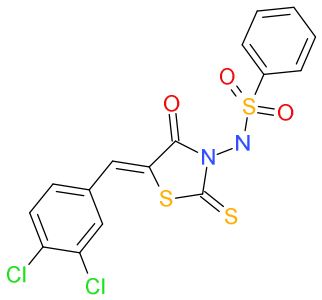

$44, \mathrm{IC}_{50}=0.2 \mu \mathrm{M}$

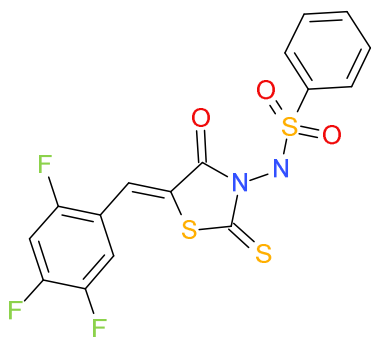

$45, \mathrm{IC}_{50}=0.2 \mu \mathrm{M}$

\section{Acyl pyrrolidines}

In an attempt to identify an alternate treatment option for Hepatitis C infection, George Burton et al. identified a series of N-acyl pyrrolidines [e. g. Compound 46] as inhibitors of NS5B[132]. Further, to improve the potency and to address the issues of the poor cell penetration and poor drug-like properties a series of analogues were developed by replacement of one of the carboxylic acid of compound 46, the most potent among them was compounded 47 with an IC 50 value of $0.04 \mu \mathrm{M}$ [133].

GSK625433 is an acyl pyrrolidine; mutations conferring resistance to this compound include I447F and M414T

\section{Aryl dihydrouracil}

Yaya Liu et al. through high throughput screening identified a series of aryl dihydrouracil derivatives and were tested for anti-NS5B activity. The most potent compound [48] of the series inhibited genotype $1 \mathrm{~b}$ polymerase with an $\mathrm{IC}_{50}$ value of $0.4 \mu \mathrm{M}[134]$.

\section{Proline sulfonamides}

Ariamala Gopalsamy et al. identified proline sulfonamide $\mathbf{4 9}$ with an $\mathrm{IC}_{50}$ of $3.1 \mu \mathrm{M}$ as a potent inhibitor of NS5B through high throughput screening. Optimization of compound $\mathbf{4 9}$ resulted in many analogues with good potency and selectivity; the most potent of them is compound $\mathbf{5 0}$ with an IC 50 value of $0.08 \mu \mathrm{M}$ [135]. 


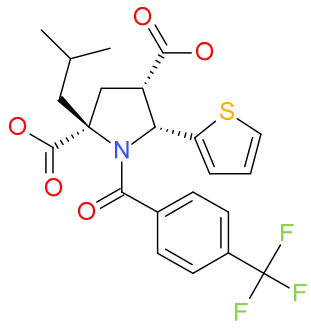

$46, \mathrm{IC}_{50}=0.3 \mu \mathrm{M}$

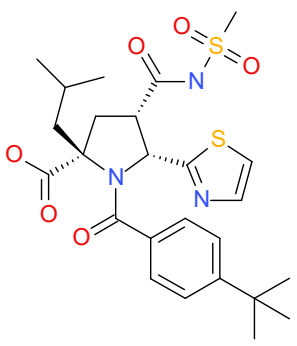

$47, \mathrm{IC}_{50}=0.04 \mu \mathrm{M}$<smiles>COc1cc([N+](=O)[O-])c(N2CCC(=O)NC2=O)cc1C(C)(C)C</smiles>

48, $\mathrm{IC}_{50}=0.4 \mu \mathrm{M}$<smiles>Cc1cc(S(=O)(=O)N2CCCC2C(=O)O)c(N)cc1Cl</smiles>

49, $\mathrm{IC}_{50}=3.1 \mu \mathrm{M}$<smiles>O=C(O)C1CCCN1S(=O)(=O)c1cc(Cl)c(Cl)c(Cl)c1O</smiles>

$50, \mathrm{IC}_{50}=0.08 \mu \mathrm{M}$

\section{Acrylic acid derivatives}

Pfefferkorn et al. identified a lead compound PNU-248809 (51), a modest inhibitor of NS5B C $\Delta 21$ by high throughput screening. They have drawn the following SAR conclusions by modifying A and B rings in the template (52) [136].<smiles>O=C(O)/C(=C/c1ccc(-c2ccccc2)o1)NC(=O)c1ccccc1</smiles>

PNU-248809 [51]<smiles>[R3]c1ccc(-[Y]2ccccc2)c([R1])c1[R]</smiles>

[52]<smiles>O=C(O)/C(=C/c1ccc(Oc2ccccc2Cl)cc1)NC(=O)c1ccccc1</smiles>

$53, \mathrm{IC}_{50}=0.20 \mu \mathrm{M}$<smiles>O=C(O)/C(=C/c1ccc(Oc2ccccc2I)cc1)NC(=O)c1ccccc1</smiles>

$54, \mathrm{IC}_{50}=0.04 \mu \mathrm{M}$
Phenyl ether at A ring (Compound 53) and small hydrophobic substituents at R1 position of B ring are preferred. In order to improve the activity of compound 53, Jeffrey A. Pfefferkorn et al. generated analogues by changing substituents at R1 position of Bring. Substitutions at the meta and para positions of $\mathrm{B}$ ring are deleterious. In the case of monosubstituted analogues, halogens were more preferred at R1 position and the activity increased with the size of the halogen. The most potent of this series is compound 54.

\section{Fluoropyridones}

Schoenfeld et al. through structure based drug designing discovered a series of non-nucleoside inhibitors and optimization of these analogues generated compound 55, a fluoropyridone derivative which showed nanomolar potency against HCV-NS5B. It inhibited 4 isoforms of Cytochrome P450 [1A4, 2C9, 2C19, 2D6], and exhibited high metabolic stability in both in vitro and in vivo. But the only limitation was poor oral absorption, which was corrected by using a 
lipid-based formulation. It showed robust anti-NS5B potency against a panel of 17 different clinical isolates from both genotype $1 \mathrm{a}$ and $1 \mathrm{~b}$ with an $\mathrm{EC}_{50}$ value ranging from 0.4-6.8 $\mathrm{nM}$ [137].<smiles>COc1c(/C=C/c2ccc(NS(C)(=O)=O)cc2)cc(-c2cc(F)c[nH]c2=O)cc1C(C)(C)C</smiles>

$$
\begin{gathered}
55, \text { IC }_{50}=1-3 \mathrm{nM} \\
\mathrm{EC}_{50}[\mathrm{GT1} 1 \mathrm{a}]=8 \mathrm{nM} \\
\mathrm{EC}_{50}[\mathrm{GT1b}]=3 \mathrm{nM}
\end{gathered}
$$

\section{Indoles}

High throughput screening of NS5B using non-trinucleotide primed assay revealed indole derivatives exemplified by compound 56 , which inhibited NS5B with an IC50 value of $0.9 \mu \mathrm{M}$ but showed poor activity in the replicon assay[138,139]. Efforts made by Anilkumar et al. To<smiles>O=C(O)c1c(-c2ccccc2F)c2cc(Cl)ccc2n1Cc1ccccc1</smiles>

$$
56, \mathrm{IC}_{50}=0.9 \mu \mathrm{M}
$$
$\mathrm{EC}_{50}=>100 \mu \mathrm{M}$<smiles>CS(=O)(=O)NC(=O)c1c(-c2ccc[nH]c2=O)c2cc(Cl)ccc2n1Cc1ccnc(N)c1</smiles>

$60, \mathrm{IC}_{50}=0.9 \mu \mathrm{M}$ $\mathrm{EC}_{50}=>100 \mu \mathrm{M}$<smiles>O=C(O)c1c(-n2c(=O)[nH]c3cscc3c2=O)c2cc(C(F)(F)F)ccc2n1Cc1ccc(F)cc1F</smiles>

57, $\mathrm{IC}_{50}=0.059 \mu \mathrm{M}$ $\mathrm{EC}_{50}=12 \mu \mathrm{M}$<smiles>Nc1cc(Cn2c(C3=NS(=O)(=O)c4ccccc4N3)c(-c3ccc[nH]c3=O)c3cc(Cl)ccc32)ccn1</smiles>

61, $\mathrm{IC}_{50}=0.059 \mu \mathrm{M}$ $\mathrm{EC}_{50}=12 \mu \mathrm{M}$
Cheng et al. developed a series of pyridine carboxamide derivatives which bind to palm I site of NS5B. Some of them showed low nanomolar potency in enzyme inhibition assay [genotype 1b] and submicromolar potency in cell-based replicon assay[142]. improve the cell-based activity involved the optimization of substituents at N1 and C3 positions of compound 56. However, none of the designed compounds showed significant activity in the cell-based replicon assay[140].

Further optimization by the addition of clinked heterocycle analogues such as pardon and pyrimidinedione at C3 position, halogen substituted benzyl group or amino substituted pyridine at $\mathrm{N} 1$ position and CF3 at C5 position of compound 56 resulted in compounds 57, 58 and 59 with a good activity profile in enzyme assays and cell-based Replicon assay[140]. These compounds form bidentate hydrogen bond interactions with a backbone of Tyr-448 and Ile-447.

Later the same group of scientists tried to replace the acid group at C2 position to further optimize the indole derivatives. Acyl sulphonamide at $\mathrm{C} 2$ position improved the binding affinity and replicon activity (Compound 60) [141]. Heterocyclic modification with sulphonamide group also showed an excellent activity profile (compound 61), but acyl groups are more preferred as they act as tethers for the addition of new functional groups.

Further optimization at the $\mathrm{C} 2$ position resulted in phenyl acyl sulfonamide series of analogs [compound 62 and 63] with $2 \log$ fold improvement in enzyme activity [142].<smiles>Nc1cc(Cn2c(C(=O)O)c(-n3c(=O)[nH]c4cscc4c3=O)c3cc(C(F)(F)F)ccc32)ccn1</smiles>

$58, \mathrm{IC}_{50}=0.032 \mu \mathrm{M}$

$\mathrm{EC}_{50}=1.4 \mu \mathrm{M}$<smiles>CS(=O)(=O)Nc1cccc(S(=O)(=O)NC(=O)c2c(-c3ccc[nH]c3=O)c3cc(Cl)ccc3n2Cc2ccnc(N)c2)c1</smiles>

$62, \mathrm{IC}_{50}=0.039 \mu \mathrm{M}$ $\mathrm{EC}_{50}=0.011 \mu \mathrm{M}$<smiles>Nc1cc(Cn2c(C(=O)O)c(-c3ccc[nH]c3=O)c3cc(C(F)(F)F)ccc32)ccn1</smiles>

59, $\mathrm{IC}_{50}=0.017 \mu \mathrm{M}$

$\mathrm{EC}_{50}=0.3 \mu \mathrm{M}$<smiles>CS(=O)(=O)Nc1cccc(S(=O)(=O)NC(=O)c2c(-c3ccc[nH]c3=O)c3cc(Cl)ccc3n2Cc2ccccc2F)c1</smiles>

63, $\mathrm{IC}_{50}=0.018 \mu \mathrm{M}$

$\mathrm{EC}_{50}=0.02 \mu \mathrm{M}$
The other class of inhibitors that bind to site III are 1, 5benzodiazepines. These showed IC $_{50}$ values in the range of 3-9 $\mu \mathrm{M}$ in biochemical assays. The site III non-nucleoside inhibitors that are currently in different phases of development are given in Table 6.

Table 6: Direct acting Non-nucleoside palm I inhibitors

\begin{tabular}{lll}
\hline Molecule & Clinical phase & Company \\
\hline GSK625433 & Phase 1 & GlaxoSmithKline \\
ANA598 & Discontinued & Anadys/Roche \\
[Setrobuvir] & & \\
ABT-333 [Dasabuvir] & Launched & AbbVie \\
ABT-072 & Discontinued & AbbVie \\
\hline
\end{tabular}

*Clinical phase details of all compounds are captured from Adisinsight 
Currently, Setrobuvir is being studied in combination with peginterferon and Ribavirin in phase 2 trials [NCT01903954]. It is very effective in phase 2 trials but the emergence of M414T, M414L, G554D mutants reduced the efficacy [143]. ABT-333 in combination with ABT-450 a protease inhibitor, Ombitasvir and ribavirin showed $96 \%$ survival rate in HCV genotype $1 \mathrm{~b}$ infected patients having cirrhosis [144]. In a phase Ila study the triple combination regimen ABT- $450 / \mathrm{r}$ [combined with ritonavir] and ABT- 072 with ribavirin showed survival rate in $9 / 11$ patients infected with HCV genotype 1 at $36 \mathrm{w}$ post-treatment [145].

\section{Site IV [Palm II]}

Benzofuran-C3-carboxamide [HCV796] is a class of inhibitors that bind at site IV. The binding site of HCV796 is different from the binding site of benzothiadiazines. HCV796 binds to residues in the primer grip site. S365T, C316Y, and M414T mutations in NS5B rendered resistance to HCV796 both in replicons and in biochemical, enzymatic assays[146]. HCV796 has an excellent inhibitory profile and approved by FDA for phase II trial but was later discontinued due to its hepatotoxic effects.

Another potent inhibitor of this class is a boronic acid derivative GSK5852, which is more potent than HCV796 and was active against C316Y mutants. Voitenleitner et al. reported that GSK5852 showed good anti-HCV activity with EC50 values in the nanomolar range against $\mathrm{HCV}$ genotypes 1 and 2 and has an excellent resistant profile. This molecule is currently in clinic $[147,148]$. The Palm II nonnucleoside inhibitors that are currently in different phases of development are given in Table 7.

Table 7: Direct acting non-nucleoside palm II inhibitors

\begin{tabular}{lll}
\hline Molecule & Clinical phase & Company \\
\hline GS-9190 [Tegobuvir] & Phase 2 & Gilead \\
IDX375 & Discontinued & Idenix \\
HCV-79 & Discontinued & Viropharma/Wyeth \\
GSK5852 & Phase 2 & GlaxoSmithKline \\
PPI-383 & Phase 1 & Presidio Pharmaceuticals, Inc. \\
\hline
\end{tabular}

${ }^{*}$ Clinical phase details of all compounds are captured from Adisin sight

Tegobuvir has a unique mechanism of action and is distinct from other NNIs of NS5B [149]. Tegobuvir undergoes metabolic activation resulting in glutathione adducts which specifically interacts with NS5B thereby inhibiting viral replication [149]. PPI-383 is a nonnucleoside inhibitor with pan-genotypic activity; it exhibits $\mathrm{EC}_{50}$ value of $8.3 \mathrm{nM}, 2.2 \mathrm{nM}$ against genotypes $1 \mathrm{a}$ and $1 \mathrm{~b}$ respectively in cell-based replicon assays. It is also active against HCV genotypes $2 \mathrm{a}$, 3a and 4a [ $\mathrm{EC}_{50} \mathrm{~s}$ in the 4.4-11.7 nM) [150]. Currently, the Phase 1b trials have been completed for this compound [NCT01928147].

Combinations of different classes of drugs are being tried and many of these are in clinical trials. NS5A inhibitors (Ombitasvir, Daclatasvir, Ledipasvir and MK-8742) are tried in combination with protease inhibitors and NS5B inhibitors. Those that have advanced to Phase III are listed in Table 8.

Table 8: Combination therapies targeting HCV in clinical, developmental Phase III

\begin{tabular}{lll}
\hline Combination & Clinical phase & Company \\
\hline Ombitasvir [ABT-267]+Dasabuvir [ABT-450]+ritonavir & Phase III [submitted to FDA 4/21/2014] & AbbVie \\
Asunaprevir+Daclatasvir+Beclabuvir [BMS-791325] & Phase III & Bristol-Myers Squibb \\
\hline
\end{tabular}

\section{Effect of NS5B genotypic variation on inhibitor response}

HCV exists in 7 different genotypes and within each genotype are several subtypes which differ with respect to viral sequence and geographic distribution [151]. HCV genotype 1 and 3 are more prevalent globally compared to other genotypes [152]. The active site region of NS5B is conserved among all the genotypes and Nucleoside inhibitors target the active site and hence exhibit cross genotypic effect[20]. The Non-nucleoside inhibitors bind to distinct allosteric sites presents on thumb I, Thumb II, Palm I and Palm II regions. The sequence at these regions are variable and hence Nonnucleoside inhibitors does not exhibit pan-genotypic activity [20]. In fact, significant differences in response to NNI have been noted within different viral sequences isolated from the same individual [153]. So the differences in viral genotypes can be the major factors for therapeutic failure. Clearly, more genotypic analysis is required to improve the strategies for development of potential anti-HCV agents.

\section{DISCUSSION}

Hepatitis $\mathrm{C}$ is a chronic inflammatory liver disease which will lead to Liver fibrosis, liver cirrhosis, liver carcinoma and liver failure. Though HCV infection was identified in the 1970's, the research was stalled due to unavailability of in vitro and in vivo experimental system. Later in 1999 the availability of the HCV replicon system fueled the development of anti-HCV agents, but the HCV drug discovery rate was slow. Till 2011 the standard care of treatment for Hepatitis $\mathrm{C}$ was a combination of pegylated interferon and Ribavirin given for a period of 24 to $48 \mathrm{w}$. But this treatment regimen was effective in only $50-60 \%$ of patients and is associated with severe side effects. In 2011 first generation NS3 protease inhibitors namely telaprevir [Incivek], Boceprevir [Victrelis] were approved by FDA after which a second generation protease inhibitor Simeprevir [Olysio] was launched in 2013. However, these were effective against only HCV genotype I infected patients. Later, many effective NS3/4a inhibitors [Paritaprevir, grazoprevir], NS5B inhibitors [Sofosbuvir and Dasabuvir], and NS5A inhibitors [Ledipasvir, ombitasvir, daclatasvir, elbasvir, velpatasvir] were launched in the recent years. But, unsuccessful response to these therapies was seen in a small percentage of patients and this need to be considered. Treatment failure in this population is due to relapse [viral load is reduced significantly or undetected at the end of the therapy followed by a rebound to pretreatment levels once the treatment is discontinued]. The major cause of relapse is the emergence of resistance-associated variants (RAV).

The RAV can emerge in either the NS3 or the NS5B or the NS5A or sometimes in two regions. The most common RAVs in NS5B region include S282T and C316Y and persistence of these are highly variable. While RAVs in the NS3 region diminish over time, and those in the NS5A region are long lasting. Treatment options in this intolerant patient population depend on the causes of, treatment failure, the composition of the initial treatment regimen and severity of the disease. For example, is a patient is intolerant to PEGIFN/RBV the treatment option could be to use DAAs and if it is due to RAVs to NS5A inhibitor then the treatment regimen should be NS5A inhibitor-free or use of a different NS5A inhibitor. However, very less amount of data is available to conclude on which treatment regimens are best fit for treatment failure patients and hence leaving room for drug development opportunities in HCV research. 


\section{CONCLUSION}

In the recent years, there has been rapid progress in $\mathrm{HCV}$ research and effective therapies targeting viral enzymes, namely NS3, NS5A and NS5B were launched in the market. However, the high cost of the medications limits their universal use, hence there exists a need for cost effective therapies. Also, handling of DAA associated RAVs is a major challenge. In future HCV research should aim at the development of therapies for non-responder patient population and treatment regimens with short duration of treatment, even less than $12 \mathrm{w}$.

\section{ABBREVIATION}

HCV-Hepatitis C virus, NS5B-nonstructural protein 5B, NINucleoside inhibitors, NNI-Non-nucleoside inhibitors, NTPNucleotide triphosphate, PK-Pharmacokinetics, GTP-Guanosine-5'triphosphate, RAV-Resistance-associated Variants, DAA-Direct acting antivirals

\section{ACKNOWLEDGEMENT}

I thank Dr. Vadivelan Sankaran for his guidance and technical assistance. I acknowledge Dr. Satyanarayana Eleswarapu for reviewing and concluding the article.

\section{CONFLICTS OF INTERESTS}

\section{Declared none}

\section{REFERENCES}

1. Orlando R, Lirussi F. Hepatitis C virus infection: sexual or nonsexual transmission between spouses? A case reports and reviews of the literature. Infection 2007;35:465-8.

2. El-Serag HB. Hepatocellular carcinoma: recent trends in the United States. Gastroenterology 2004;127(5 Suppl 1):S27-34.

3. Lai ME, Mazzoleni AP, Argiolu F, De Virgilis S, Balestrieri A, Purcell RH, et al. Hepatitis C virus in multiple episodes of acute hepatitis in poly transfused thalassaemic children. Lancet [London, England] 1994;343:388-90.

4. Cohen J. The scientific challenge of hepatitis C. Science 1999;285:26-30.

5. Averhoff FM, Glass N, Holtzman D. Global burden of hepatitis C: considerations for healthcare providers in the United States. Clin Infect Dis 2012;55 Suppl 1:S10-5.

6. Kwong AD. The HCV revolution did not happen overnight. ACS Med Chem Lett 2014;5:214-20.

7. Jaroszewicz J, Flisiak R, Dusheiko G. A pill for HCV-myth or foreseeable future? Liver Int 2014;34:6-11.

8. Kao, Chinnaswamy. An update on small molecule inhibitors of the HCV NS5B polymerase: effects on RNA synthesis in vitro and in cultured cells, and potential resistance in viral quasispecies. Virus Adapt Treat 2010;2:73-89.

9. Kayali Z, Schmidt WN. Finally sofosbuvir: an oral anti-HCV drug with wide performance capability. Pharmacogenomics Pers Med 2014;7:387-97.

10. Drug Pipeline-Quick Reference Guides. Available from: http://hcvadvocate.org/treatment/drug-pipeline/\#Quick. [Last accessed on 10 Jul 2016].

11. Powdrill MH, Bernatchez Ja, Götte M. Inhibitors of the hepatitis C virus RNA-dependent RNA polymerase NS5B. Viruses 2010;2:2169-95.

12. Lindenbach BD, Rice CM. Unraveling hepatitis C virus replication from genome to function. Nature 2005;436:933-8.

13. Ivashkina N, Wölk B, Lohmann V, Bartenschlager R, Blum HE, Penin $\mathrm{F}$, et al. The hepatitis $\mathrm{C}$ virus RNA-dependent RNA polymerase membrane insertion sequence is a transmembrane segment. J Virol 2002;76:13088-93.

14. Schmidt-Mende J, Bieck E, Hugle T, Penin F, Rice CM, Blum HE, et al. Determinants for membrane association of the hepatitis C virus RNA-dependent RNA polymerase. J Biol Chem 2001;276:44052-63.

15. Le Pogam S, Seshaadri A, Kosaka A, Chiu S, Kang H, Hu S, et al. Existence of hepatitis $\mathrm{C}$ virus NS5B variants naturally resistant to non-nucleoside, but not to a nucleoside, polymerase inhibitors among untreated patients. J Antimicrob Chemother 2008;61:1205-16.

16. Jiao P, Xue W, Shen Y, Jin N, Liu H. Understanding the drug resistance mechanism of hepatitis C virus NS5B to PF-
00868554 due to mutations of the 423 site: a computational study. Mol BioSyst 2014;10:767-77.

17. Ferraris P, Blanchard E, Roingeard P. Ultrastructural and biochemical analyses of hepatitis $C$ virus-associated host cell membranes. J Gen Virol 2010;91[Pt 9]:2230-7.

18. Romero-Brey I, Merz A, Chiramel A, Lee JY, Chlanda P, Haselman U, et al. Three-dimensional architecture and biogenesis of membrane structures associated with hepatitis C virus replication. PLoS Pathog 2012;8:e1003056.

19. Beaulieu PL, Tsantrizos YS. Inhibitors of the HCV NS5B polymerase: new hope for the treatment of hepatitis $C$ infections. Curr Opin Invest Drugs 2004;5:838-50.

20. Herlihy KJ, Graham JP, Kumpf R, Patick AK, Duggal R, Shi ST. Development of intergenotypic chimeric replicons to determine the broad-spectrum antiviral activities of hepatitis $\mathrm{C}$ virus polymerase inhibitors. Antimicrob Agents Chemother 2008;52:3523-31.

21. Poijärvi-Virta P. Prodrug approaches of nucleotides and oligonucleotides. Curr Med Chem 2006;13:3441-65.

22. Lavie A, Konrad M. Structural requirements for efficient phosphorylation of nucleotide analogs by human thymidylate kinase. Mini Rev Med Chem 2004;4:351-9.

23. Quinazoline derivatives as medicaments. W02005032481A2; 2004.

24. Eldrup AB, Allerson CR, Bennett CF, Bera S, Bhat B, Bhat N, et al. Structure-activity relationship of purine ribonucleosides for inhibition of hepatitis C virus RNA-dependent RNA polymerase. J Med Chem 2004;47:2283-95.

25. Carroll SS, Tomassini JE, Bosserman M, Getty K, Stahlhut MW, Eldrup $\mathrm{AB}$, et al. Inhibition of hepatitis $\mathrm{C}$ virus RNA replication by 2'-modified nucleoside analogs. J Biol Chem 2003;278:11979-84.

26. Deore RR, Chern JW. NS5B RNA-dependent RNA polymerase inhibitors: the promising approach to treating hepatitis $C$ virus infections. Curr Med Chem 2010;17:3806-26.

27. Eldrup AB, Prhavc M, Brooks J, Bhat B, Prakash TP, Song Q, et al. Structure-activity relationship of hetero based-modified 2'C-methyl ribonucleosides as inhibitors of hepatitis C virus RNA replication. J Med Chem 2004;47:5284-97.

28. McGuigan C, Madela K, Aljarah M, Gilles A, Brancale A, Zonta N, et al. Design, synthesis and evaluation of a novel double prodrug: INX-08189. A new clinical candidate for hepatitis $C$ virus. Bioorg Med Chem Lett 2010;20:4850-4.

29. Nucleosides with anti-hepatitis B Virus activity. US20020019363A1; 2009.

30. Weller S, Blum MR, Doucette M, Burnette T, Cederberg DM, de Miranda $\mathrm{P}$, et al. Pharmacokinetics of the acyclovir prodrug valaciclovir after escalating single and multiple-dose administration to normal volunteers. Clin Pharmacol Ther 1993;54:595-605.

31. Pierra C, Amador A, Benzaria S, Cretton-Scott E, D'Amours M, Mao J, et al. Synthesis and pharmacokinetics of valopicitabine [NM283], an efficient prodrug of the potent anti-HCV agent 2'C-methylcytidine. J Med Chem 2006;49:6614-20.

32. Valopicitabine [NM283] plus peg-interferon in treatment-naive hepatitis C patients with HCV genotype-1 infection: HCV RNA Clearance During $24 \mathrm{~W}$ of Treatment; 2007.

33. Clark JL, Hollecker L, Mason JC, Stuyver LJ, Tharnish PM, Lostia $\mathrm{S}$, et al. Design, synthesis, and antiviral activity of 2'-deoxy-2'fluoro-2'-C-methylcytidine, a potent inhibitor of hepatitis $\mathrm{C}$ virus replication. J Med Chem 2005;48:5504-8.

34. Perrone P, Luoni GM, Kelleher MR, Daverio F, Angell A, Mulready S, et al. Application of the phosphoramidite ProTide approach to 4'-azidouridine confers sub-micromolar potency versus hepatitis $C$ virus on an inactive nucleoside. J Med Chem 2007;50:1840-9.

35. Klumpp K, Lévêque V, Le Pogam S, Ma H, Jiang WR, Kang H, et al. The novel nucleoside analog R1479 [4'-azidocytidine] is a potent inhibitor of NS5B-dependent RNA synthesis and hepatitis C virus replication in cell culture. J Biol Chem 2006;281:3793-9.

36. Stuyver LJ, Whitaker T, McBrayer TR, Hernandez-Santiago BI, Lostia S, Tharnish PM, et al. Ribonucleoside analogue that blocks replication of bovine viral diarrhea and hepatitis $\mathrm{C}$ 
viruses in culture. Antimicrob Agents Chemother 2003; 47:244-54.

37. Stuyver LJ, McBrayer TR, Whitaker T, Tharnish PM, Ramesh M, Lostia $\mathrm{S}$, et al. Inhibition of the subgenomic hepatitis $\mathrm{C}$ virus replicon in huh-7 cells by 2'-deoxy-2'-fluorocytidine. Antimicrob Agents Chemother 2004;48:651-4.

38. Wendt A, Adhoute X, Castellani P, Oules V, Ansaldi C, Benali S, et al. Chronic hepatitis C: future treatment. Clin Pharmacol 2014;6:1-17.

39. Sofia MJ, Bao D, Chang W, Du J, Nagarathnam D, Rachakonda S, et al. Discovery of a $\beta-\mathrm{d}-2^{\prime}$-deoxy-2'- $\alpha$-fluoro-2'- $\beta$-Cmethyluridine nucleotide prodrug [PSI-7977] for the treatment of hepatitis C virus. J Med Chem 2010;53:7202-18.

40. Sulkowski MS, Gardiner DF, Rodriguez-Torres M, Reddy KR, Hassanein T, Jacobson I, et al. Daclatasvir plus sofosbuvir for previously treated or untreated chronic HCV infection. N Engl J Med 2014;370:211-21.

41. Jonckers THM, Vandyck K, Vandekerckhove L, Hu L, Tahri A, Van Hoof $\mathrm{S}$, et al. Nucleotide prodrugs of 2'-deoxy-2'spirooxetane ribonucleosides as novel inhibitors of the $\mathrm{HCV}$ NS5B polymerase. J Med Chem 2014;57:1836-44.

42. Kao CC, Singh P, Ecker DJ. De novo initiation of viral RNAdependent RNA synthesis. Virology 2001;287:251-60.

43. Witkowski JT, Robins RK, Khare GP, Sidwell RW. Synthesis and antiviral activity of 1,2,4-triazole-3-thiocarboxamide and 1,2,4triazole-3-carboxamidine ribonucleosides. J Med Chem 1973;16:935-7.

44. Lin C, Yeh LT, Vitarella D, Hong Z. Viramidine, a prodrug of ribavirin, shows better liver-targeting properties and safety profiles than ribavirin in animals. Antiviral Chem Chemother 2003;14:145-52.

45. Marcellin P, Gish RG, Gitlin N, Heise J, Halliman DG, Chun E, et al. Safety and efficacy of viramidine versus ribavirin in ViSER2:randomized, double-blind study in therapy-naive hepatitis C patients. J Hepatol 2010;52:32-8.

46. Zhu R, Wang M, Xia Y, Qu F, Neyts J, Peng L. Arylethynyltriazole a cyclo nucleosides inhibit hepatitis $\mathrm{C}$ virus replication. Bioorg Med Chem Lett 2008;18:3321-7.

47. Koh YH, Shim JH, Girardet JL, Hong Z. Design and evaluation of a potential mutagen for hepatitis $\mathrm{C}$ virus. Bioorg Med Chem Lett 2007;17:5261-4.

48. Summa V, Petrocchi A, Pace P, Matassa VG, De Francesco R, Altamura S, et al. Discovery of alpha,gamma-diketo acids as potent selective and reversible inhibitors of hepatitis $\mathrm{C}$ virus NS5b RNA-dependent RNA polymerase. J Med Chem 2004:47:14-7.

49. Di Francesco ME, Avolio S, Pompei M, Pesci S, Monteagudo E, Pucci V, et al. Synthesis and antiviral properties of novel 7heterocyclic substituted 7-deaza-adenine nucleoside inhibitors of hepatitis C NS5B polymerase. Bioorg Med Chem 2012;20:4801-11.

50. Manfroni G, Cannalire R, Barreca ML, Kaushik-Basu N, Leyssen P, Winquist J, et al. The versatile nature of the 6-aminoquinolone scaffold: identification of submicromolar hepatitis C virus NS5B inhibitors. J Med Chem 2014;57:1952-63.

51. Cho A, Zhang L, Xu J, Lee R, Butler T, Metobo S, et al. Discovery of the first C-nucleoside HCV polymerase inhibitor [GS-6620] with demonstrated antiviral response in HCV-infected patients. J Med Chem 2014;57:1812-25.

52. Murakami E, Wang T, Babusis D, Lepist EI, Sauer D, Park Y, et al. Metabolism and pharmacokinetics of the anti-hepatitis $\mathrm{C}$ virus nucleotide prodrug GS-6620. Antimicrob Agents Chemother 2014;58:1943-51.

53. Antiviral Activity and resistance emergence: combinations of the NS5B nucleotide inhibitor ACH-3422 with other antiviral agents in vitro. Available from: http://www.natap.org/2014/ AASLD/AASLD_44.htm. [Last accessed on 10 Jun 2016].

54. ACH-3422, a Novel Nucleotide Prodrug Inhibitor of HCV NS5B Polymerase. Available from: http://www.natap.org/ 2015/ EASL/EASL_99.htm. [Last accessed on 10 Jun 2016].

55. Medivir-News-Press Releases. Available from: http://www. medivir.se/v5/en/uptodate/pressrelease.cfm?releaseid=1639 EA2C5103B43Dandyear=2011. [Last accessed on 10 Jun 2016].

56. DDIs [drug-drug interactions] in the evolving HCV treatment landscape. Available from: http://www.natap.org/ 2014/ Pharm/Pharm_46.htm. [Last accessed 25 Jan 2016].
57. Tomei L, Altamura S, Bartholomew L, Biroccio A, Ceccacci A, Pacini L, et al. Mechanism of action and antiviral activity of benzimidazole-based allosteric inhibitors of the hepatitis $\mathrm{C}$ virus RNA-dependent RNA polymerase. J Virol 2003;77:13225-31.

58. McKercher G, Beaulieu PL, Lamarre D, LaPlante S, Lefebvre S, Pellerin C, et al. Specific inhibitors of HCV polymerase identified using an NS5B with lower affinity for template/primer substrate. Nucleic Acids Res 2004;32:422-31.

59. Di Marco S, Volpari C, Tomei L, Altamura S, Harper S, Narjes F, et al. Interdomain communication in hepatitis $\mathrm{C}$ virus polymerase abolished by small molecule inhibitors bound to a novel allosteric site. J Biol Chem 2005;280:29765-70.

60. Mayhoub AS. Hepatitis C RNA-dependent RNA polymerase inhibitors: a review of structure-activity and resistance relationships; different scaffolds and mutations. Bioorg Med Chem Elsevier 2012;20:3150-61.

61. Kukolj G, McGibbon GA, McKercher G, Marquis M, Lefèbvre S, Thauvette L, et al. Binding site characterization and resistance to a class of non-nucleoside inhibitors of the hepatitis $\mathrm{C}$ virus NS5B polymerase. J Biol Chem 2005;280:39260-7.

62. LaPlante SR, Cameron DR, Aubry N, Lefebvre S, Kukolj G, Maurice $\mathrm{R}$, et al. Solution structure of substrate-based ligands when bound to hepatitis C virus NS3 protease domain. J Biol Chem 1999;274:18618-24.

63. Ishida T, Suzuki T, Hirashima S, Mizutani K, Yoshida A, Ando I, et al. Benzimidazole inhibitors of hepatitis C virus NS5B polymerase: identification of 2-[[4-diarylmethoxy]phenyl]benzimidazole. Bioorg Med Chem Lett 2006;16:1859-63.

64. Beaulieu PL, Bös M, Bousquet Y, Fazal G, Gauthier J, Gillard J, et al. Non-nucleoside inhibitors of the hepatitis C virus NS5B polymerase: discovery and preliminary SAR of benzimidazole derivatives. Bioorg Med Chem Lett 2004;14:119-24.

65. Beaulieu PL, Bös M, Bousquet Y, DeRoy P, Fazal G, Gauthier J, et al. Non-nucleoside inhibitors of the hepatitis C virus NS5B polymerase: discovery of benzimidazole 5-carboxylic amide derivatives with low nanomolar potency. Bioorg Med Chem Lett 2004;14:967-71.

66. Hirashima S, Suzuki T, Ishida T, Noji S, Yata S, Ando I, et al. Benzimidazole derivatives bearing substituted biphenyls as hepatitis C virus NS5B RNA-dependent RNA polymerase inhibitors: structure-activity relationship studies and identification of a potent and highly selective inhibitor JTK-109. J Med Chem 2006;49:4721-36.

67. Patil VM, R GK, Chudayeu M, Gupta SP, Samanta S, Masand N, et al. Synthesis, in vitro and in silico NS5B polymerase inhibitory activity of benzimidazole derivatives. Med Chem 2012;8:629-35.

68. Weidlich IE, Filippov IV, Brown J, Kaushik-Basu N, Krishnan R, Nicklaus MC, et al. Inhibitors for the hepatitis C virus RNA polymerase explored by SAR with advanced machine learning methods. Bioorg Med Chem 2013;21:3127-37.

69. Beaulieu PL, Gillard J, Jolicoeur E, Duan J, Garneau M, Kukolj G, et al. From benzimidazole to indole-5-carboxamide thumb pocket I inhibitors of HCV NS5B polymerase. part 1: indole C-2 SAR and discovery of diamide derivatives with nanomolar potency in cell-based subgenomic replicons. Bioorg Med Chem Lett 2011;21:3658-63.

70. Harper S, Pacini B, Avolio S, Filippo M Di, Migliaccio G, Laufer R, et al. Development and Preliminary Optimization of Indole; 2005. p. 1314-7.

71. Stansfield I, Pompei M, Conte I, Ercolani C, Migliaccio G, Jairaj $\mathrm{M}$, et al. Development of carboxylic acid replacements in indole-N-acetamide inhibitors of hepatitis C virus NS5B polymerase. Bioorg Med Chem Lett 2007;17:5143-9.

72. Ikegashira K, Oka T, Hirashima S, Noji S, Yamanaka H, Hara Y, et al. Discovery of conformationally constrained tetracyclic compounds as potent hepatitis C virus NS5B RNA polymerase inhibitors. J Med Chem 2006;49:6950-3.

73. Venkatraman S, Velazquez F, Gavalas S, Wu W, Chen KX, Nair $\mathrm{AG}$, et al. Optimization of potency and pharmacokinetics of tricyclic indole derived inhibitors of HCV NS5B polymerase. Identification of ester prodrugs with improved oral pharmacokinetics. Bioorg Med Chem 2014;22:447-58. 
74. Mcgowan D, Vendeville S, Lin T, Tahri A, Hu L, Cummings MD, et al. Bioorganic and medicinal chemistry letters finger-loop inhibitors of the HCV NS5b polymerase. part 1: discovery and optimization of novel 1, 6-and 2, 6-macrocyclic indole series. Bioorg Med Chem Lett 2012;22:4431-6.

75. Vendeville S, Lin TI, Hu L, Tahri A, McGowan D, Cummings MD, et al. Finger loop inhibitors of the HCV NS5b polymerase. Part II. Optimization of tetracyclic indole-based macrocycle leading to the discovery of TMC647055. Bioorg Med Chem Lett 2012;22:4437-43.

76. Cummings MD, Lin TI, Hu L, Tahri A, McGowan D, Amssoms K, et al. Discovery and early development of TMC647055, a nonnucleoside inhibitor of the hepatitis C virus NS5B polymerase. J Med Chem 2014;57:1880-92.

77. Velázquez F, Venkatraman S, Lesburg CA, Duca J, Rosenblum $\mathrm{SB}$, Kozlowski JA, et al. Synthesis of new 4,5dihydrofuranoindoles and their evaluation as HCV NS5B polymerase inhibitors. Org Lett 2012;14:556-9.

78. Gentles RG, Ding M, Bender JA, Bergstrom CP, Grant-Young K, Hewawasam $\mathrm{P}$, et al. Discovery and preclinical characterization of the cyclopropyl indol benzazepine BMS-791325, a potent allosteric inhibitor of the hepatitis C virus NS5B polymerase. J Med Chem 2014;57:1855-79.

79. Rong F, Chow S, Yan S, Larson G, Hong Z, Wu J. Structureactivity relationship [SAR] studies of quinoxalines as novel HCV NS5B RNA-dependent RNA polymerase inhibitors. Bioorg Med Chem Lett 2007;17:1663-6.

80. Ontoria JM, Martìn Hernando JI, Malancona S, Attenni B, Stansfield I, Conte I, et al. Identification of thieno[3,2b]pyrroles as allosteric inhibitors of hepatitis C virus NS5B polymerase. Bioorg Med Chem Lett 2006;16:4026-30.

81. Kaushik-Basu N, Bopda-Waffo A, Talele TT, Basu A, Costa PRR, da Silva AJM, et al. Identification and characterization of coumestans as novel HCV NS5B polymerase inhibitors. Nucleic Acids Res 2008;36:1482-96.

82. Lemm JA, Liu M, Gentles RG, Ding M, Voss S, Pelosi LA, et al. Preclinical characterization of BMS-791325, an allosteric inhibitor of hepatitis C Virus NS5B polymerase. Antimicrob Agents Chemother 2014;58:3485-95.

83. Rigat KL, Lu H, Wang YK, Argyrou A, Fanslau C, Beno B, et al. Mechanism of inhibition for BMS-791325, a novel nonnucleoside inhibitor of hepatitis C virus NS5B polymerase. J Biol Chem 2014;289:33456-68.

84. Muir AJ, Poordad F, Lalezari J, Everson G, Dore GJ, Herring R, et al. Daclatasvir in combination with asunaprevir and beclabuvir for hepatitis $C$ virus genotype 1 infection with compensated cirrhosis. JAMA 2015;313:1736-44.

85. Program F, Book A. Global Antiviral Journal; 2009. p. 5.

86. Safety and Antiviral Activity of NS5B Polymerase Inhibitor MK3281in Genotype 1 and 3 HCV-Infected Patients; 2009.

87. Zeuzem S, Dufour JF, Buti M, Soriano V, Buynak RJ, Mantry P, et al. Interferon-free treatment of chronic hepatitis $\mathrm{C}$ with faldaprevir, deleobuvir and ribavirin: SOUND-C3, a phase $2 \mathrm{~b}$ study. Liver Int 2015;35:417-21.

88. Zeuzem S, Soriano V, Asselah T, Bronowicki JP, Lohse AW, Müllhaupt B, et al. Faldaprevir and deleobuvir for HCV genotype 1 infection. N Engl J Med 2013;369:630-9.

89. Devogelaere B, Berke JM, Vijgen L, Dehertogh P, Fransen E, Cleiren E, et al. TMC647055, a potent nonnucleoside hepatitis C virus NS5B polymerase inhibitor with cross-genotypic coverage. Antimicrob Agents Chemother 2012;56:4676-84.

90. Erhardt A, Deterding K, Benhamou Y, Reiser M, Forns X, Pol S, et al. Safety, pharmacokinetics and antiviral effect of BILB 1941, a novel hepatitis C virus RNA polymerase inhibitor, after $5 \mathrm{~d}$ oral treatment. Antivir Ther 2009;14:23-32.

91. Wang M, Ng KKS, Cherney MM, Chan L, Yannopoulos CG, Bedard J, et al. Non-nucleoside analogue inhibitors bind to an allosteric site on HCV NS5B polymerase. Crystal structures and mechanism of inhibition. J Biol Chem 2003;278:9489-95.

92. Yan S, Appleby T, Larson G, Wu JZ, Hamatake R, Hong Z, et al. Structure-based design of a novel thiazolone scaffold as HCV NS5B polymerase allosteric inhibitors. Bioorg Med Chem Lett 2006;16:5888-91.
93. Yan S, Larson G, Wu JZ, Appleby T, Ding Y, Hamatake R, et al. Novel thiazolones as HCV NS5B polymerase allosteric inhibitors: further designs, SAR, and complex X-ray structure. Bioorg Med Chem Lett 2007;17:63-7.

94. Al-Ansary GH, Ismail MAH, Abou El Ella DA, Eid S, Abouzid KAM. Molecular design and synthesis of HCV inhibitors based on thiazolone scaffold. Eur J Med Chem 2013;68:19-32.

95. Beaulieu PL, Coulombe R, Duan J, Fazal G, Godbout C, Hucke O, et al. Structure-based design of novel HCV NS5B thumb pocket 2 allosteric inhibitors with submicromolar gt1 replicon potency: discovery of a quinazolinone chemotype. Bioorg Med Chem Lett 2013;23:4132-40.

96. Love RA, Parge HE, Yu X, Hickey MJ, Diehl W, Gao J, et al. Crystallographic identification of a noncompetitive inhibitor binding site on the hepatitis C virus NS5B RNA polymerase enzyme. J Virol 2003;77:7575-81.

97. Chan L, Pereira O, Reddy TJ, Das SK, Poisson C, Courchesne M, et al. Discovery of thiophene-2-carboxylic acids as potent inhibitors of HCV NS5B polymerase and HCV subgenomic RNA replication. Part 2: tertiary amides. Bioorg Med Chem Lett 2004;14:797-800.

98. Chan L, Das SK, Reddy TJ, Poisson C, Proulx M, Pereira O, et al. Discovery of thiophene-2-carboxylic acids as potent inhibitors of HCV NS5B polymerase and HCV subgenomic RNA replication. Part 1: sulfonamides. Bioorg Med Chem Lett 2004;14:793-6.

99. Chan L, Reddy TJ, Proulx M, Das SK, Pereira O, Wang W, et al. Identification of $\mathrm{N}, \mathrm{N}$-disubstituted phenylalanines as a novel class of inhibitors of hepatitis C NS5B polymerase. J Med Chem 2003;46:1283-5.

100. Reddy TJ, Chan L, Turcotte N, Proulx M, Pereira OZ, Das SK, et al. Further SAR studies on novel small molecule inhibitors of the hepatitis C [HCV] NS5B polymerase. Bioorg Med Chem Lett 2003;13:3341-4.

101. Howe AYM, Cheng H, Thompson I, Chunduru SK, Herrmann S, O'Connell J, et al. Molecular mechanism of a thumb domain hepatitis C virus nonnucleoside RNA-dependent RNA polymerase inhibitor. Antimicrob Agents Chemother 2006;50:4103-13.

102. Gopalsamy A, Lim K, Ciszewski G, Park K, Ellingboe JW, Bloom J, et al. Discovery of pyrano[3,4-b]indoles as potent and selective HCV NS5B polymerase inhibitors. J Med Chem 2004;47:6603-8.

103. Jackson RW, LaPorte MG, Herbertz T, Draper TL, Gaboury JA, Rippin SR, et al. The discovery and structure-activity relationships of pyrano[3,4-b]indole-based inhibitors of hepatitis C virus NS5B polymerase. Bioorg Med Chem Lett 2011;21:3227-31.

104. LaPorte MG, Draper TL, Miller LE, Blackledge CW, Leister LK, Amparo E, et al. The discovery and structure-activity relationships of pyrano[3,4-b]indole based inhibitors of hepatitis C virus NS5B polymerase. Bioorg Med Chem Lett 2010;20:2968-73.

105. Li H, Tatlock J, Linton A, Gonzalez J, Borchardt A, Dragovich P, et al. Identification and structure-based optimization of novel dihydropyrone as potent HCV RNA polymerase inhibitors. Bioorg Med Chem Lett 2006;16:4834-8.

106. Andres CJ, Bronson JJ, D'Andrea SV, Deshpande MS, Falk PJ, Grant-Young KA, et al. 4-Thiazolidinones: novel inhibitors of the bacterial enzyme MurB. Bioorg Med Chem Lett 2000;10:715-7.

107. Küçükgüzel SG, Oruç EE, Rollas S, Sahin F, Ozbek A. Synthesis, characterization and biological activity of novel 4thiazolidinones, 1,3,4-oxadiazoles, and some related compounds. Eur J Med Chem 2002;37:197-206.

108. Karali N, İllhan E, Gürsoy A, Kiraz M. New cyclohexylidenehydrazide and 4-aza-1-thiaspiro[4.5]decan-3one derivatives of 3 -phenyl-4[3H]-quinazolinones. Farm 1998;53:346-9.

109. Fahmy HT. Synthesis of some new triazoles as potential antifungal agents. Boll Chim Farm 2001;140:422-7.

110. Ergenç N, Capan G. Synthesis and anticonvulsant activity of new 4-thiazolidone and 4-thiazoline derivatives. Farm 1994;49:133-5. 
111. Capan G, Ulusoy N, Ergenç N, Cevdet Ekinci A, Vidin A. Synthesis and anticonvulsant activity of new 3-[[2furyl]carbonyl]amino-4-thiazolidinone and 2-[[2-furyl] carbonyl] hydrazono-4-thiazoline derivatives. Farm 1996;51:729-32.

112. Bukowski L, Janowiec M, Zwolska-Kwiek Z, Andrzejczyk Z. Some reactions of 2-cyanomethylimidazo[4,5-b]pyridine with isothiocyanates. The antituberculosis activity of the obtained compounds. Pharmazie 1998;53:373-6.

113. Babaoglu K, Page MA, Jones VC, McNeil MR, Dong C, Naismith $\mathrm{JH}$, et al. Novel inhibitors of an emerging target in Mycobacterium tuberculosis; substituted thiazolidinones as inhibitors of dTDP-rhamnose synthesis. Bioorg Med Chem Lett 2003;13:3227-30.

114. Rawal RK, Katti SB, Kaushik-Basu N, Arora P, Pan Z. Nonnucleoside inhibitors of the hepatitis $C$ virus NS5B RNAdependant RNA polymerase: 2-Aryl-3-heteroaryl-1,3thiazolidin-4-one derivatives. Bioorg Med Chem Lett 2008;18:6110-4.

115. Küçükgüzel I, Satılmış G, Gurukumar KR, Basu A, Tatar E, Nichols DB, et al. 2-Heteroarylimino-5-arylidene-4thiazolidinones as a new class of non-nucleoside inhibitors of HCV NS5B polymerase. Eur J Med Chem 2013;69:931-41.

116. Nittoli T, Curran K, Insaf S, DiGrandi M, Orlowski M, Chopra R, et al. Identification of anthranilic acid derivatives as a novel class of allosteric inhibitors of hepatitis C NS5B polymerase. J Med Chem 2007;50:2108-16.

117. Stammers T a, Coulombe R, Duplessis M, Fazal G, Gagnon A, Garneau M, et al. Anthranilic acid-based thumb pocket 2 HCV NS5B polymerase inhibitors with sub-micromolar potency in the cell-based replicon assay. Bioorg Med Chem Lett 2013;23:6879-85.

118. May MM, Brohm D, Harrenga A, Marquardt T, Riedl B, Kreuter J, et al. Discovery of substituted N-phenylbenzene sulphonamides as a novel class of non-nucleoside hepatitis $\mathrm{C}$ virus polymerase inhibitors. Antiviral Res 2012;95:182-91.

119. Beaulieu PL. Filibuvir, a non-nucleoside NS5B polymerase inhibitor for the potential oral treatment of chronic HCV infection. I Drugs 2010;13:938-48.

120. Cooper C, Lawitz EJ, Ghali P, Rodriguez-Torres M, Anderson FH, Lee SS, et al. Evaluation of VCH-759 monotherapy in hepatitis C infection. J Hepatol 2009;51:39-46.

121. Jiang M, Zhang EZ, Ardzinski A, Tigges A, Davis A, Sullivan JC, et al. Genotypic and phenotypic analyses of hepatitis $\mathrm{C}$ virus variants observed in clinical studies of VX-222, a nonnucleoside NS5B polymerase inhibitor. Antimicrob Agents Chemother 2014;58:5456-65.

122. Sofosbuvir+ledipasvir or GS-9669 | CATIE-Canada's source for HIV and hepatitis C information; 2013.

123. Nyanguile O, Pauwels F, Van den Broeck W, Boutton CW, Quirynen L, Ivens T, et al. 1,5-benzodiazepines, a novel class of hepatitis $\mathrm{C}$ virus polymerase nonnucleoside inhibitors. Antimicrob Agents Chemother 2008;52:4420-31.

124. Dhanak D, Duffy KJ, Johnston VK, Lin-Goerke J, Darcy M, Shaw $\mathrm{AN}$, et al. Identification and biological characterization of heterocyclic inhibitors of the hepatitis $C$ virus RNA-dependent RNA polymerase. J Biol Chem 2002;277:38322-7.

125. Tomei L, Altamura S, Bartholomew L, Bisbocci M, Bailey C, Bosserman $\mathrm{M}$, et al. Characterization of the inhibition of hepatitis $\mathrm{C}$ virus RNA replication by nonnucleosides. J Virol 2004;78:938-46.

126. Pratt JK, Donner P, McDaniel KF, Maring CJ, Kati WM, Mo H, et al. Inhibitors of HCV NS5B polymerase: synthesis and structure-activity relationships of N-1-heteroalkyl-4hydroxyquinolon-3-yl-benzothiadiazines. Bioorg Med Chem Lett 2005;15:1577-82.

127. Zhou Y, Webber SE, Murphy DE, Li L-S, Dragovich PS, Tran CV, et al. Novel HCV NS5B polymerase inhibitors derived from 4[1',1'-dioxo-1',4'-dihydro-1'lambda6-benzo[1',2',4'] thiadiazin3'-yl]-5-hydroxy-2H-pyridazin-3-ones. Part 1:exploration of 7'substitution of benzothiadiazine. Bioorg Med Chem Lett 2008;18:1413-8.

128. Zhou Y, Li LS, Dragovich PS, Murphy DE, Tran CV, Ruebsam F, et al. Novel HCV NS5B polymerase inhibitors derived from 4- [1',1'-dioxo-1',4'-dihydro-1'lambda[6]-

benzo[1',2',4'] thiadiazin-3'-yl]-5-hydroxy-2H-pyridazin-3-ones. Part 2: variation of the 2-and 6-pyridazinone substituents. Bioorg Med Chem Lett 2008;18:1419-24.

129. Li LS, Zhou Y, Murphy DE, Stankovic N, Zhao J, Dragovich PS, et al. Novel HCV NS5B polymerase inhibitors derived from 4[1',1'-dioxo-1',4'-dihydro-1'lambda[6]-

benzo[1',2',4']thiadiazin-3'-yl]-5-hydroxy-2H-pyridazin-3-ones. Part 3:Further optimization of the 2-, 6-, and 7'-substituents and initial pharmacokinetic assessme. Bioorg Med Chem Lett 2008;18:3446-55.

130. Randolph JT, Flentge CA, Huang PP, Hutchinson DK, Klein LL, Lim HB, et al. Synthesis and biological characterization of Bring amino analogues of potent benzothiadiazide hepatitis $\mathrm{C}$ virus polymerase inhibitors. J Med Chem 2009;52:3174-83.

131. Powers JP, Piper DE, Li Y, Mayorga V, Anzola J, Chen JM, et al. SAR and mode of action of novel non-nucleoside inhibitors of hepatitis C NS5b RNA polymerase. J Med Chem 2006;49:103446.

132. Burton G, Ku TW, Carr TJ, Kiesow T, Sarisky RT, Lin-Goerke J, et al. Identification of small molecule inhibitors of the hepatitis $\mathrm{C}$ virus RNA-dependent RNA polymerase from a pyrrolidine combinatorial mixture. Bioorg Med Chem Lett 2005;15:1553-6.

133. Burton G, Ku TW, Carr TJ, Kiesow T, Sarisky RT, Lin-Goerke J, et al. Studies on acyl pyrrolidine inhibitors of HCV RNAdependent RNA polymerase to identify a molecule with replicon antiviral activity. Bioorg Med Chem Lett 2007;17:1930-3.

134. Liu Y, Lim BH, Jiang WW, Flentge CA, Hutchinson DK, Madigan DL, et al. Identification of aryl dihydrouracil derivatives as palm initiation site inhibitors of HCV NS5B polymerase. Bioorg Med Chem Lett 2012;22:3747-50.

135. Gopalsamy A, Chopra R, Lim K, Ciszewski G, Shi M, Curran KJ, et al. Discovery of proline sulfonamides as potent and selective hepatitis $C$ virus NS5b polymerase inhibitors. Evidence for a new NS5b polymerase binding site. J Med Chem 2006;49:3052-5.

136. Pfefferkorn Ja, Greene ML, Nugent Ra, Gross RJ, Mitchell Ma, Finzel BC, et al. Inhibitors of HCV NS5B polymerase. Part 1: evaluation of the southern region of [2Z]-2-[benzoylamino]-3[5-phenyl-2-furyl]acrylic acid. Bioorg Med Chem Lett 2005;15:2481-6.

137. Schoenfeld RC, Bourdet DL, Brameld KA, Chin E, de Vicente J, Fung A, et al. Discovery of a novel series of potent nonnucleoside inhibitors of hepatitis C virus NS5B. J Med Chem 2013;56:8163-82.

138. Ferrari E, He Z, Palermo RE. Hepatitis C virus NS5B polymerase exhibits distinct nucleotide requirements for initiation and elongation. J Biol Chem 2008;283:33893-901.

139. Cheng CC, Shipps GW, Yang Z, Kawahata N, Lesburg CA, Duca JS, et al. Inhibitors of hepatitis $\mathrm{C}$ virus polymerase: synthesis and characterization of novel 2-oxy-6-fluoro-N-[[S]-1-hydroxy-3phenylpropan-2-yl]-benzamides. Bioorg Med Chem Lett 2010;20:2119-24.

140. Anilkumar GN, Lesburg CA, Selyutin O, Rosenblum SB, Zeng Q, Jiang Y, et al. I. Novel HCV NS5B polymerase inhibitors: discovery of indole 2-carboxylic acids with C3-heterocycles. Bioorg Med Chem Lett 2011;21:5336-41.

141. Anilkumar GN, Selyutin O, Rosenblum SB, Zeng Q, Jiang Y, Chan TY, et al. II. Novel HCV NS5B polymerase inhibitors: discovery of indole C2 acyl sulfonamides. Bioorg Med Chem Lett 2012;22:713-7.

142. Cheng CC, Huang X, Shipps GW, Wang YS, Wyss DF, Soucy KA, et al. Pyridine carboxamides: potent palm site inhibitors of HCV NS5B polymerase. ACS Med Chem Lett 2010;1:466-71.

143. Xue W JPLHYX. Molecular modeling and residue interaction network studies on the mechanism of binding and resistance of the HCV NS5B polymerase mutants to VX-222 and ANA598. Antivir Res 2014;104:40-51.

144. Poordad F, Hezode C, Trinh R, Kowdley KV, Zeuzem S, Agarwal $\mathrm{K}$, et al. ABT-450/r-ombitasvir and dasabuvir with ribavirin for hepatitis C with cirrhosis. N Engl J Med 2014;370:1973-82.

145. Lawitz E, Poordad F, Kowdley KV, Cohen DE, Podsadecki T, Siggelkow $\mathrm{S}$, et al. A phase 2 a trial of 12-week interferon-free therapy with two direct-acting antivirals [ABT-450/r, ABT- 
072] and ribavirin in IL28B C/C patients with chronic hepatitis C genotype 1. J Hepatol 2013;59:18-23.

146. Howe AYM, Cheng H, Johann S, Mullen S, Chunduru SK, Young DC, et al. Molecular mechanism of hepatitis $C$ virus replicon variants with reduced susceptibility to a benzofuran inhibitor, HCV-796. Antimicrob Agents Chemother 2008;52:3327-38.

147. Maynard A, Crosby RM, Ellis B, Hamatake R, Hong Z, Johns BA, et al. Discovery of a potent boronic acid derived inhibitor of the HCV RNA-dependent RNA polymerase. J Med Chem 2014;57:1902-13.

148. Voitenleitner C, Crosby R, Walker J, Remlinger K, Vamathevan J, Wang A, et al. In vitro characterization of GSK2485852, a novel hepatitis $\mathrm{C}$ virus polymerase inhibitor. Antimicrob Agents Chemother 2013;57:5216-24.

149. Hebner CM, Han B, Brendza KM, Nash M, Sulfab M, Tian Y, et al. The HCV non-nucleoside inhibitor Tegobuvir utilizes a novel mechanism of action to inhibit NS5B polymerase function. PLoS One 2012;7:e39163.
150. Presidio Pharmaceuticals Announces a New Clinical Candidate, PPI-383, a Novel Pan-Genotypic Non-Nucleoside Polymerase Inhibitor for HCV | Reuters; 2012.

151. Simmonds P, Alberti A, Alter HJ, Bonino F, Bradley DW, Brechot $\mathrm{C}$, et al. A proposed system for the nomenclature of hepatitis $\mathrm{C}$ viral genotypes. Hepatology 1994;19:1321-4.

152. Messina JP, Humphreys I, Flaxman A, Brown A, Cooke GS, Pybus OG, et al. Global distribution and prevalence of hepatitis $C$ virus genotypes. Hepatology 2014;61:77-87.

153. Ludmerer SW, Graham DJ, Boots E, Murray EM, Simcoe A, Markel EJ, et al. Replication fitness and NS5B drug sensitivity of diverse hepatitis $\mathrm{C}$ virus isolates characterized by using a transient replication assay. Antimicrob Agents Chemother 2005;49:2059-69.

\section{How to cite this article}

- $\quad$ Prasanthi Polamreddy, Vinita Vishwakarma, Rambabu Gundla. A review on anti-HCV agents targeting active site and allosteric sites of non-structural protein 5B [NS5B]. Int J Pharm Pharm Sci 2016;8(11):1-18. 